IZA DP No. 10144

Schooling and Labor Market Effects of Temporary Authorization: Evidence from DACA

Catalina Amuedo-Dorantes

Francisca Antman

August 2016

Forschungsinstitut zur Zukunft der Arbeit Institute for the Study of Labor 


\title{
Schooling and Labor Market Effects of Temporary Authorization: Evidence from DACA
}

\author{
Catalina Amuedo-Dorantes \\ San Diego State University \\ and IZA \\ Francisca Antman \\ University of Colorado Boulder \\ and IZA
}

\section{Discussion Paper No. 10144 \\ August 2016}

\author{
IZA \\ P.O. Box 7240 \\ 53072 Bonn \\ Germany \\ Phone: +49-228-3894-0 \\ Fax: +49-228-3894-180 \\ E-mail: iza@iza.org
}

Any opinions expressed here are those of the author(s) and not those of IZA. Research published in this series may include views on policy, but the institute itself takes no institutional policy positions. The IZA research network is committed to the IZA Guiding Principles of Research Integrity.

The Institute for the Study of Labor (IZA) in Bonn is a local and virtual international research center and a place of communication between science, politics and business. IZA is an independent nonprofit organization supported by Deutsche Post Foundation. The center is associated with the University of Bonn and offers a stimulating research environment through its international network, workshops and conferences, data service, project support, research visits and doctoral program. IZA engages in (i) original and internationally competitive research in all fields of labor economics, (ii) development of policy concepts, and (iii) dissemination of research results and concepts to the interested public.

IZA Discussion Papers often represent preliminary work and are circulated to encourage discussion. Citation of such a paper should account for its provisional character. A revised version may be available directly from the author. 


\section{ABSTRACT \\ Schooling and Labor Market Effects of Temporary Authorization: Evidence from DACA*}

This paper explores the labor market and schooling effects of the Deferred Action for Childhood Arrivals (DACA) initiative, which provides work authorization to eligible immigrants along with a temporary reprieve from deportation. The analysis relies on a difference-indifferences approach that exploits the discontinuity in program rules to compare eligible individuals to ineligible, likely undocumented immigrants before and after the program went into effect. To address potential endogeneity concerns, we focus on youths that likely met DACA's schooling requirement when the program was announced. We find that DACA reduced the probability of school enrollment of eligible higher-educated individuals, as well as some evidence that it increased the employment likelihood of men, in particular. Together, these findings suggest that a lack of authorization may lead individuals to enroll in school when working is not a viable option. Thus, once employment restrictions are relaxed and the opportunity costs of higher-education rise, eligible individuals may reduce investments in schooling.

JEL Classification: J15, J61, J2, J3

Keywords: undocumented immigrants, work authorization

Corresponding author:

Francisca M. Antman

Department of Economics

University of Colorado Boulder

256 UCB

Boulder, CO 80309

USA

E-mail: francisca.antman@colorado.edu

\footnotetext{
* We thank Kelly Bedard, Sarah Bohn, Brian Cadena, Seema Jayachandran, Terra McKinnish, Anita Alves Pena, Audrey Singer, Stephen J. Trejo, Klaus Zimmermann, three anonymous referees, seminar participants at the IZA Annual Migration Meeting, University of Southern California and Colegio de la Frontera, along with session participants at the annual meetings of the American Economic Association, Population Association of America and Western Economic Association International. Any errors are our own.
} 


\section{Introduction}

Immigration reform is again the subject of heated debate in the American political system, media, and public at large. One of the most contentious issues is whether immigration reform should include a path to citizenship for unauthorized immigrants already in the United States -a population estimated to be about 11.7 million in 2012 (Passel et al. 2013). Within this debate, special attention has been paid to whether a path to legalization should be offered to unauthorized immigrants who came to the United States as children. Advocates of these youths have pushed forward variants of the Development, Relief, and Education for Alien Minors (DREAM) Act over the past decade. As immigration reform and DREAM Act legislation stalled at the national level, on June 15, 2012, President Barack Obama announced that his administration would practice prosecutorial discretion for individuals meeting a set of criteria very similar to those proposed in the most recent version of the DREAM Act (Preston and Cushman 2012). ${ }^{1}$ Under this program, individuals approved for consideration of deferred action are granted a renewable two-year reprieve from deportation proceedings and become eligible for work authorization in the United States.

In this paper, we exploit the implementation of DACA to revisit a topic of great concern in the immigration debate - the extent to which work authorization can affect the schooling and labor market outcomes of undocumented workers. ${ }^{2}$ In principle, the expected impact of DACA on these outcomes is uncertain. One might expect that eligible individuals will be more likely to be employed given that the work authorization relaxes the employment constraints faced by

\footnotetext{
${ }^{1}$ DACA eligibility rules are outlined in the Background section below.

${ }^{2}$ Given the policy significance of DACA, interested parties have begun surveying DACA applicants to measure its impacts. Notably, Gonzales and Bautista-Chavez (2014) report that almost 60 percent of survey respondents found a new job, even though most were already at work prior to DACA. School enrollment effects are not reported. Nonetheless, lack of information on the selection of survey participants and on survey non-response rates make it difficult to compare their findings with those reported here.
} 
undocumented migrants. However, most of these individuals might have already been working informally, in which case the work authorization granted by DACA might have little impact on their employment likelihood. ${ }^{3}$ The anticipated effect of DACA on schooling is similarly difficult to pin down. Proponents of DREAM Act legislation have often argued that authorization incentivizes previously undocumented youths to invest more in schooling since it allows them to more fully reap the rewards of education (National Immigration Law Center 2005, Immigration Policy Center 2012). Nevertheless, undocumented youths are likely to heavily discount future earnings, and may only view schooling as a second-best alternative to working given the less stringent legal requirements to register in school. Thus, DACA could represent an increase in the opportunity cost of schooling for eligible individuals and, consequently, lead to a drop in schooling investments by individuals who already meet DACA's educational eligibility requirements. ${ }^{4}$ Additionally, uncertainty about the continuity of the program under future administrations may have curbed its overall impacts. These ambiguities underscore the importance of examining the empirical questions we look at herein.

DACA provides a special opportunity to make these assessments because the recovery of the causal effect of work authorization on schooling and labor market outcomes is generally plagued with self-selection and endogeneity concerns. Put simply, those individuals who choose to pursue and ultimately

\footnotetext{
${ }^{3}$ It may be seen in other labor market outcomes, however, such as wages and type of occupation. We also explore these outcomes below.

${ }^{4}$ This is analogous to the explanation offered in Charles et al. (2013), who suggest that housing booms resulted in an increase in the opportunity cost of college and thus an observed drop in enrollments at community colleges. Similar effects of local labor market conditions on educational attainment are found in Evans and Kim (2008) and Black, McKinnish, and Sanders
} (2005). 
obtain work authorization are likely to be different from those that do not in unobservable ways that are also correlated with their labor market performance. Thus, a naïve comparison of the labor market outcomes of individuals that have obtained work authorization and of individuals who have not will generally fail to reveal a causal impact.

We avoid these problems by adopting a quasi-experimental approach that relies on an intent-to-treat strategy and compares individuals who were eligible for the DACA program to other likely undocumented immigrants who were not eligible before and after the policy went into effect. To bolster the case that our estimates are driven by plausibly exogenous variation and simplify the interpretation, we also present results which exploit the discontinuity in a single eligibility rule. While information on legal status is not observable to us, we begin with a sample of foreign-born non-citizens and, subsequently, perform robustness checks focusing on populations more likely to be undocumented, such as Hispanic and Mexican non-citizens. To get around the endogeneity of schooling choice inherent in the DACA eligibility rules, we also focus on youths that would likely have met DACA's schooling eligibility requirement at the time the program was announced. According to Batalova et al. (2013), an estimated 76 percent of DACA eligible youth have earned a high school diploma or its equivalent, making this a sensible restriction. Furthermore, to alleviate any remaining concerns regarding the likely unauthorized immigration status of nonDACA eligible individuals in our control group, we also perform robustness checks that restrict the analysis to foreign-born non-citizens with more than 5 years of U.S. residency -typically the maximum duration of student visas.

Our paper is similar in spirit to the study by Gathmann and Keller (2013), who examine the returns to citizenship in Germany by evaluating the impact of a change in program rules that affected eligibility for citizenship. More broadly, this research is also closely related to the wider discussion about the goals of 
immigration policy in developed nations and how labor market outcomes vary with migrants' legal status (see for example Constant and Zimmermann 2005a and 2005b). In this case, however, we explore the returns to obtaining a two-year reprieve from deportation and work authorization relative to the counterfactual of remaining unauthorized -a more relevant policy concern in the United States today owing to its large population of undocumented immigrants. In this sense, our study also shares much in common with the literature examining the impact of legalization under the 1986 Immigration Reform and Control Act (IRCA) on immigrants' labor market outcomes (see for example Rivera-Batiz, 1999; Kossoudji and Cobb-Clark, 2002; and Amuedo-Dorantes et al., 2007). Of course, one important distinction between IRCA and DACA is that the latter favored relatively young and educated immigrants. Thus, one might expect the schooling impacts of legalization which were under-studied after IRCA to be of greater interest under DACA. Given the uncertainty surrounding the continuity of DACA, as well as the millions of undocumented immigrants that have arrived in the two and a half decades between the two reforms, one may also question whether similar impacts should be expected.

We find that, despite the short time period that has elapsed since the enactment of DACA, the policy has already had a significant impact on eligible individuals. In particular, we find evidence that the program reduced the probability of school enrollment of eligible higher-educated individuals and that it increased the likelihood of employment among eligible men. Together, these results suggest that undocumented individuals may over-invest in education in the absence of legal work permits, so that when a program such as DACA is implemented, employment outcomes may improve while school enrollments fall. This is consistent with an increased opportunity cost of college education for eligible individuals once DACA went into effect. 
The paper is organized as follows. Section II describes the DACA program in greater detail, focusing on its enactment, eligibility requirements, as well as on its application and approval rates. Section III describes the data and presents summary statistics on the sample used in the analysis, while Section IV outlines our empirical strategy and Section V presents our findings on the impact that DACA is having on the schooling and labor market outcomes of eligible undocumented youth. We also present the results of a separate identification strategy where we exploit only the age at arrival eligibility criterion to simplify the results and interpretation. We find that the impact of DACA on eligible individuals is similar regardless of the empirical approach, thus suggesting that our main results are driven by exogenous variation. In Section VI, we perform a series of robustness checks to: (a) confirm the lack of pre-existing trends prior to the implementation of DACA; (b) ensure that we are likely dealing with undocumented immigrants and DACA-applicants by focusing our attention to individuals with characteristics of actual DACA-applicants (such as their state of residency, ethnicity and time in the United States) and, lastly, (c) experiment with different assumptions regarding the effective date of treatment. Finally, Section VII summarizes our main findings and concludes the paper.

\section{Background}

As mentioned above, DACA's roots are closely tied to DREAM Act proposals, which preceded DACA by over a decade. Nevertheless, the timing and political context in which DACA was announced cannot be overlooked. Its origins lie in the lead-up to the presidential election in late 2012, which resulted in a battle for Latino votes in the face of a potential alternative to the DREAM act presented by Mr. Obama's challengers (Wallsten 2012). All this contributed to a political environment in which DACA was announced suddenly and implemented swiftly. For purposes of evaluating the impact of DACA, this suggests that there 
were relatively little anticipation effects leading up to the program's announcement.

Although DACA does not offer the more permanent immigration status embedded in DREAM Act proposals, it does provide qualified individuals with a two-year reprieve from deportation proceedings and the ability to obtain work authorization in the United States. At the expiration of the two-year period, program beneficiaries can apply for a renewal of their DACA status, with renewals issued in two-year increments. Eligibility rules under DACA also closely mirror those suggested in variants of DREAM Act legislation. Namely, U.S. Citizenship and Immigration Services (USCIS) stipulates that an individual eligible for DACA must: (1) Be under the age of 31 as of June 15, 2012; (2) Have arrived in the United States before reaching his $16^{\text {th }}$ birthday; (3) Have continuously resided in the United States since June 15, 2007, up until the time of application (4) Have been physically present in the United States on June 15, 2012, and at the time of making the request for deferred action with USCIS; (5) Have entered without inspection prior to June 15, 2012, or had his lawful immigration status expired by that date; (6) Be currently in school, have graduated from high school or obtained an equivalent degree, or have been honorably discharged from the Coast Guard or Armed Forces of the United States; and (7) Have no criminal records or pose a threat to national security or public safety. ${ }^{5}$ For purposes of the analysis, we focus on those eligibility criteria observable to researchers given the data available -namely, age as of 2012, age at arrival in the United States, arrival prior to June 2007, and educational attainment/enrollment. These are also likely to be the most relevant determinants of eligibility from a practical point of view.

\footnotetext{
${ }^{5}$ For greater details, visit the section entitled: "Consideration of Deferred Action for Childhood Arrivals Process" at http://www.uscis.gov
} 
A final note that is critical for the analysis concerns the date of implementation of the DACA program, which defines the dividing line between the pre- and post-DACA periods. Although USCIS began to accept DACA applications on August 15, 2012, relatively few cases were actually approved until October 2012 (Passel and Lopez 2012, Batalova et al. 2013). Figure 1 shows the number of approved DACA cases in the year after applications were first accepted in August 2012. As highlighted in the figure, only 1,687 cases were approved in September 2012, whereas in excess of 28,000 were approved each month thereafter (U.S. Citizenship and Immigration Services, 2013). Hence, except in some robustness checks, we define the Post-DACA period as October 2012 onwards.

\section{Data and Descriptive Statistics}

\section{A. Sample Considerations}

To evaluate how DACA is impacting the schooling, employment and wages of eligible youth, we use individual micro-level data from the monthly Current Population Survey (CPS) spanning from January 2000 through March 2014. The CPS provides detailed information on the labor force status, hourly wages, educational attainment, race/ethnicity, and other basic demographics, such as the decade of arrival for those born outside the United States. With regard to information on current schooling investments, the CPS is more limited. Over the time period being examined, the CPS asks only if individuals between the ages of 16 and 24 were enrolled in high school, college, or university at the time of the survey. Respondents who answer yes were then asked whether they enrolled fullor part-time.

As our focus is on the impact of DACA on schooling investments and labor market outcomes of eligible youth, we limit the sample to working-age individuals who were asked about schooling in the CPS -namely 16 to 24 year 
olds. Furthermore, since one of DACA's eligibility requirements has to do explicitly with schooling, we must also ensure that our estimate of the impact of DACA is not confounded by any selection into schooling. With that aim, we further restrict our sample to individuals 18 to 24 years old who likely met the DACA schooling eligibility requirement as of its announcement. Since we do not have information on the year in which respondents earned their high school degree or GED, we assume the vast majority did so by age 18. Focusing on 18 to 24 year olds ensures that the schooling and employment related impacts of DACA we observe are not driven by individuals' decision to pursue schooling in order to qualify for deferred deportation itself and the potential endogeneity issues which that implies. ${ }^{6}$ Additionally, it encompasses the broadest group of DACA applicants, who are on average 20 years old (Wong et al. 2013).

One useful feature of the CPS is that it contains information on the type of occupation in which respondents are employed. We make use of these data by grouping occupations into high and low-skill occupations. ${ }^{7}$ This classification will enable us to test whether DACA permitted eligible individuals to move into higher-skill occupations-where verification of legal status and higher compensation may be more likely. On the other hand, DACA may have reduced eligible individuals' tendencies to get a high-skilled job if they rushed into getting a job and placed their plans for a post-secondary education on hold.

\section{B. Capturing Undocumented Immigrants and DACA Applicants}

\footnotetext{
${ }^{6}$ Our results are substantially similar if we use a slightly older age cut-off and restrict the sample to individuals ages 20 to 24 with a high school or GED degree. Nevertheless, we present the results for the larger group of 18 to 24 year-olds with a high school degree or GED to preserve sample size.

${ }^{7}$ For example, we place "computer and mathematical sciences occupations" in the high-skill category and "food preparation and serving related occupations" in the low-skill category. The full classification of occupations into high- and low-skill can be found in Appendix Table A1.
} 
One important limitation of the CPS is that it lacks sensitive information on individuals' legal status. Consequently, it is reasonable to question whether the ineligibles in our sample consist of an undocumented control group, especially given that the undocumented are traditionally less educated than the sample we work with. As such, some may be concerned that the control group may be made up of individuals who immigrated with the purpose of getting an educational degree in the United States, as is the case with F1 and J1 visa holders. ${ }^{8}$

To address this concern, in a series of robustness checks, we further restrict our attention to a group of immigrants previously shown to be a good representation of the most likely unauthorized. In that regard, Passel and Cohn (2009, 2010) show that almost three-quarters of unauthorized immigrants are Hispanics, with Mexican-origin individuals comprising the majority of the population of unauthorized immigrants (almost 60 percent). Therefore, we also perform the analysis for Hispanic non-citizens and, subsequently Mexican noncitizens.

An additional concern when assessing the impact of DACA using the CPS is that we do not observe actual participation in the program. Thus, some may question whether the DACA-eligible treatment group we identify is actually representative of DACA applicants. Note, however, that our treatment group not only fulfills a collection of DACA eligibility requirements, but also displays demographic characteristics that align with the ones reported of DACA

\footnotetext{
${ }^{8}$ Foreign students with $\mathrm{F} 1$ and $\mathrm{J} 1$ visas are allowed to stay in the United States for the duration of the academic program they are admitted to, which is typically listed in the arrival-departure Form I-94 (now automated). If no specific date is listed in the I-94 Form, their admission stamp will indicate: "D/S" (duration of status), and they will be allowed to stay in the United States as long as they are pursuing a full course of study (12 units for undergraduates/ 8 units for graduates per semester) and making normal progress toward completing their academic program. The I-20 for F1 students and the DS-156 for J1 students tell exactly how long the academic program will take.
} 
applicants. The latter include having arrived in the United States at an early age, holding at least a high school degree, and having long U.S. residencies.

Still, in robustness checks, we experiment with restricting our attention to non-citizens residing in states with large populations of DACA applicants, ${ }^{9}$ as well as focusing on Hispanic and Mexican non-citizens -a particularly useful trait as the vast majority of DACA applicants are Hispanic and close to three-quarters of them were born in Mexico (Singer and Svajlenka 2013). Note that, while all these restrictions bring our sample in line with those individuals who applied for DACA, they also increase the likelihood that both eligible and ineligible individuals in our sample are undocumented immigrants. As such, restricting our sample to individuals with DACA-applicant characteristics will not only narrow the control group to a group that is more likely to be undocumented, but also narrow the treatment group to a group that were actually granted authorization under DACA.

Finally, some may be concerned with using the October 2012 cut-off date, as it was neither the DACA-announcement date nor its implementation date. To address this concern, we also experiment with using the DACA announcement date of June 2012, as well as the DACA implementation date of August 2012 (at which time applications were first received), as the onset of treatment. As both of these alternative treatment dates come before the October 2012 treatment date we use in most of the analysis, results observed under these alternative dates support the interpretation that the announcement and implementation of DACA resulted in changes in behavior consistent with the anticipation of the work authorization that would later be granted.

\footnotetext{
${ }^{9}$ These states are California, Texas, New York, Illinois, Florida, North Carolina, Arizona, Georgia, and New Jersey.
} 


\section{Descriptive Statistics}

Table 1 displays some of the characteristics of the likely unauthorized group under analysis: foreign-born non-citizens ages 18 to 24 with a high school or GED degree that was likely earned prior to the announcement of DACA. It splits the sample by eligibility status before and after DACA, allowing us to compare the samples of eligible and ineligibles before DACA went into effect. As can be seen in Table 1, there are differences across these so-called treatment and control groups. Nevertheless, they are tied to the characteristics shaping eligibility in the first place. For instance, prior to DACA, eligible individuals were slightly younger (20.7 versus 22 years of age), had spent significantly more years in the United States (12 versus 4.6 years), and had arrived to the country at a much younger age (8.6 years of age versus 17.4 years of age) than their noneligible counterparts. Because of the aforementioned differences in the eligibility criteria, it also makes sense that the two groups would differ with regards to their likelihood of being married and the number of children they might have. However, differences in other demographic characteristics, such as race and gender, as well as in the characteristics of the states where they reside, are smaller. Still, the analysis will explicitly account for all these characteristics and for unobserved heterogeneity through state fixed effects and state-specific time trends. In addition, we perform a number of robustness checks using restricted samples that are much more alike in terms of some of the more distinct dimensions, such as age, age at arrival and the corresponding time in the United States.

Table 2 further informs about pre-existing differences in our outcomes of interest between the samples of eligible and ineligibles. Moreover, it reports preliminary difference-in-differences estimates by comparing outcome variables for eligible and ineligible individuals before and after DACA's implementation without controlling for any variables. There is a marked decline in the school 
enrollment and full-time school enrollment of eligible youths of about 8 percentage points from the pre- to post-DACA periods that is statistically significant at the one percent level. At the same time, school enrollment and fulltime school enrollment is rising at sizable levels for the non-eligible comparison group by around 20 percentage points over this period, resulting in a differencein-difference estimate of a decline in schooling and a decline in full-time schooling of about 28 percentage points. We also observe a rise in 3.1 percentage points in the likelihood of employment for the eligible group, however, it is not statistically significant. Nevertheless, compared with the striking 18.3 percentage point decline in the employment rate of non-eligible youths over the same period, the difference-in-difference estimate is a rise in 21.5 percentage points that is statistically significant at the one percent level. Thus, it seems that DACA effectively protects eligible youths from the employment decline seen for the noneligible comparison group. The difference-in-difference estimates for the remaining outcomes (weekly work hours, wages, and high-skill occupation) are not statistically significant. At any rate, given the differences between eligible and non-eligible youths in Table 1, it remains to be seen whether the relatively strong results on schooling and employment seen in these summary statistics will survive once we account for their demographic characteristics and for state-level variation. The regression analysis presented below explores this question.

\section{Methodology}

Our main aim is to learn about how DACA is changing the schooling investments and labor market outcomes of eligible undocumented youth relative to those of similarly undocumented youth who prove ineligible for deferred deportation. With that aim in mind, we estimate the following benchmark regression: 


$$
\begin{aligned}
Y_{i s t}=\alpha & +\beta_{1}\left(\text { DACA }_{t} \times \text { eligible }_{i s t}\right)+\beta_{2} \text { eligible }_{i s t}+\beta_{3} \text { HSplus }_{i s t} \\
& +\beta_{4} \text { YearsinUS }_{i s t}+\sum_{j} \beta_{5, j} \text { Age }_{i j s t}+X_{i s t} \gamma+Z_{s t} \lambda+\mu_{s}+\delta_{t} \\
& +\theta_{s} t+\varepsilon_{i s t}
\end{aligned}
$$

The dependent variable $Y_{\text {ist }}$ stands for the observed schooling or labor market outcome for individual $i$ in state $s$ in period $t$. Outcomes considered include whether the individual is currently enrolled in school, enrolled full-time, currently working, working in a high-skill occupation, and the log of real hourly wages as well as the usual weekly hours of work for those employed. $D A C A_{t}$ is a dummy variable equal to 1 after October 2012 -when the first large wave of individuals received official notification that their cases had been approved. The variable eligible $_{\text {ist }}$ indicates whether the individual meets all eligibility requirements observable to researchers: (1) being under the age of 31 in June 2012, (2) having entered the United States before his or her $16^{\text {th }}$ birthday, and (3) having arrived prior to June 2007.

Note that since all individuals in the sample have at least earned a high school degree or GED by the time of DACA's announcement, all individuals will have met the education/enrollment requirement, i.e., being currently enrolled in school, having completed high school or having earned a GED. This restriction limits the potential for individuals to select into treatment after the program was announced, ensuring that our estimates are in fact driven by DACA treatment as opposed to self-selection. It also establishes eligibility as of the date the program was announced, avoiding the phasing into eligible status. Finally, by focusing on foreign-born, non-citizens between the ages of 18 and 24 years-old, we can compare individuals with the set of DACA-eligibility criteria to other likely undocumented immigrants who do not display these characteristics, before and after the policy went into effect. Further sample restrictions to Mexican immigrants in the robustness checks will bolster the case for this assessment. 
To ensure that the returns to eligibility are not driven by any one of the eligibility criteria alone, we also control for having more than a high school degree $\left(\right.$ HSplus $\left._{i s t}\right)$, years in the United States $\left(\right.$ YearsinUS $\left._{\text {ist }}\right)$, and include $j$ dummy variables controlling for the respondent's age $\left(A g e_{i j s t}\right)$. Note that the inclusion of the latter two variables together will effectively control for the age at arrival eligibility criterion. Other individual-level covariates in $X_{\text {ist }}$ include the number of own children under the age of 18 , as well as dummy variables for the respondent's gender, race, and marital status. In addition, to bolster the case that our estimates are driven by exogenous variation, we present results from a simplified identification strategy where eligibility is determined solely by small differences in one eligibility criterion.

Other controls in equation (1) include the state unemployment rate and several indicators of state immigration policy that vary over time $\left(Z_{s t}\right)$, such as an indicator for whether the state implemented any type of E-Verify mandate, omnibus immigration law or $287(\mathrm{~g})$ agreement, as well as a separate indicator for whether the state granted in-state tuition for undocumented immigrants. Finally, the model incorporates a battery of state fixed effects $\left(\mu_{s}\right)$, month-year fixed effects $\left(\delta_{t}\right)$, and state-specific linear time trends $\left(\theta_{s} t\right)$ to address any other policies and economic conditions changing at the state level. ${ }^{10}$ Standard errors are clustered at the state level.

The parameter of interest to us is $\beta_{1}$, the coefficient on the interaction term between $D A C A_{t}$ and eligible $_{\text {ist }}$. It reveals the changes in the schooling, employment and wages earned by DACA-eligible individuals after the DACA program went into effect, relative to the changes experienced by likely undocumented, DACA-ineligible individuals over the same time period. This

\footnotetext{
${ }^{10}$ Note that the inclusion of month-year fixed effects implies the main level effect of DACA $\left(D A C A_{t}\right)$ drops out of the equation due to multicollinearity.
} 
difference-in-differences estimate will inform on the returns to the two-year reprieve and work authorization granted by DACA. As is true for all differencein-differences estimators, this strategy assumes that the treatment (DACAeligible) and control (undocumented DACA-ineligible) groups would have maintained parallel trends in the absence of treatment (DACA). While this assumption is ultimately untestable, we provide support for this assumption by testing for pre-existing trends between treatment and control groups to ensure that the deviations we observe did not occur prior to the implementation of DACA.

\section{The Impact of DACA on Schooling and Employment Outcomes}

\section{A. Main Results}

To assess the impact that DACA has had on the schooling and labor market outcomes of eligible undocumented youth, we estimate equation (1). As noted earlier, our sample is composed of foreign-born, non-citizens between the ages of 18 and 24 years-old with at least a high school degree or GED. ${ }^{11}$ In the robustness section, we also present results for Mexican-born non-citizens and Hispanic non-citizens, as the latter groups are more likely to be unauthorized.

Table 3, Panel A presents the results of estimating equation (1) on the full sample of foreign-born non-citizens. Focusing first on the impact of DACA on the probability of being enrolled in school, we find that the policy generated significant effects. Specifically, the program reduced the probability of school enrollment by 11.7 percentage points or by approximately 28 percent relative to

${ }^{11}$ While we limit the sample to a more educated group for reasons noted above, some may nevertheless be interested in results for the full sample without the restriction on education, particularly given that undocumented immigrants are likely to be less-educated. Thus, we present results of estimating equation (1) on the full sample without the schooling restriction in Table A2 of the appendix. Note that an additional control for schooling level is added since the sample includes both higher- and less-educated individuals. As can be seen from Table A2, results are substantially similar to those in Table 3 . 
the overall average. Similarly, the likelihood of being enrolled in school full-time decreased by 11.5 percentage points or 33 percent relative to the overall average. At the same time, DACA was associated with an increase in the employment likelihood of 9.5 percentage points or 17 percent relative to the overall average. ${ }^{12}$ The fact that all three estimates are of similar magnitude suggests that eligible youths are dropping out of full-time schooling in order to take advantage of employment opportunities once permission to work is granted under DACA. It should also be noted that the two-year reprieve from deportation and work authorization does not appear to have significantly affected working hours, wages or the type of occupation held by eligible individuals.

Some may be concerned that these estimates look especially large given that they are intent-to-treat (ITT) estimates and participation in the program is not directly observed. To address this concern, we compare the number of first-time DACA applications received by USCIS through our treatment year of 2014 to the population believed to be immediately eligible for DACA, as estimated by the Pew Research Center. Dividing the approximately 700,000 initial applications received in 2012-14 (DHS 2015) by the 950,000 youths estimated to be immediately eligible for DACA (Passel and Lopez 2012), yields a take-up rate of about 74 percent. Scaling our estimates from Table 3, Panel A, by this take-up rate yields treatment-on-the-treated (TOT) estimates that are not much higher than the ITT estimates -namely: 15.8, 15.5, and 12.8 percentage points for the schooling enrollment, full-time schooling enrollment, and employment outcomes, respectively. The relatively high take-up rate should also assuage concerns that

\footnotetext{
${ }^{12}$ This finding is in line with those from prior studies examining the impact of legalization under the 1986 Immigration Reform and Control Act (IRCA) on labor market outcomes concluding that the latter improved undocumented workers' employment prospects, reduced their workplace vulnerabilities, or increased their job mobility and working conditions (Rivera-Batiz 1999, Kossoudji and Cobb-Clark 2002, Amuedo-Dorantes et al. 2007).
} 
eligible individuals were not availing themselves of the program and of the legitimacy of the empirical approach in that context.

\section{B. Focusing on the Age at Arrival Eligibility Criterion}

As the constructed measure of DACA eligibility is comprised of a collection of characteristics, it is useful to simplify the analysis and thus confirm that the impact of DACA estimated herein is driven by plausibly exogenous variation. To do this, we further exploit the discontinuity in one exogenous requirement determining eligibility for DACA - namely the immigrant's age at arrival in the United States. ${ }^{13}$ We do this by estimating equation (1) on the sample of individuals who arrived between the ages of 13 and 18 years old who met all other DACA eligibility criteria. The sample restrictions imply that we have a treatment group consisting of individuals who arrived at ages 13 to 15, and a control group of respondents who arrived between 16 and 18 years of age.

Results of this analysis can be found in Table 3, Panel B. Despite working with a significantly smaller sample, we continue to find that DACA appears to have reduced schooling investments, although the positive impact on the likelihood of being at work is no longer statistically different from zero. Point estimates are also somewhat larger than those found using the larger sample. This is to be expected given that we have restricted our attention to those who narrowly received benefits and those who were just denied thus making the comparison between treatment and control groups all the more striking.

\footnotetext{
${ }^{13} \mathrm{We}$ are unable to exploit the discontinuity in age at the time of DACA's announcement (eligibility requirement number 1 above) because the survey only asks schooling questions of respondents between the ages of 16 and 24 .
} 


\section{Robustness Checks}

\section{A. Support for the Parallel Trends Assumption}

As noted above, the main threat to our empirical approach is whether there existed differential trends in the schooling and labor market outcomes of eligible and ineligible youths prior to DACA that may be falsely attributed to the policy. To investigate whether that is the case, we construct indicators for each of the three years prior to DACA, interact them with the indicator for DACA eligibility, and include these interaction terms in regression (1). ${ }^{14}$ If there were pre-existing trends that could account for the DACA effect observed here, we would expect these placebo interaction terms to produce statistically significant coefficients in the same direction of the DACA impact discussed above. The results of this test are documented in Table 4, Panel A.

The main findings regarding the impact of DACA on the schooling and employment outcomes of non-citizens prevail, with no statistically significant placebo interaction terms. It is also reassuring that the DACA point estimates are similar to the ones noted in the main results, despite the inclusion of the placebo interaction terms leading up to the true DACA period. Thus, we can be reasonably confident that the schooling and employment effects discussed above can be attributed to changes that occurred in the DACA period and not to preexisting trends.

To offer further reassurance that the results are not driven by a long trend prior to DACA's implementation, we further restrict our sample to a shorter window around DACA's implementation, ranging from January 2005 through the end of our sample in March 2014. Table 4, Panel B reports the results for this time period. Consistent with the parallel trends assumption, we find that the long

\footnotetext{
${ }^{14}$ Each of these placebo indicators runs from October of the year of interest through the following September to match the timing of the DACA indicator discussed in Section II.
} 
pre-period is not driving our results, as point estimates and significance levels survive this restriction on the data. Finally, in Panel C, we perform a falsification test in which we further cut the sample in Panel B to a pre-period sample extending from 2005 through 2011, and falsely designate the DACA period as starting in 2009. ${ }^{15}$ We find that there is no statistically significant impact of the pseudo-DACA indicator interacted with the eligibility indicator. This is consistent with no pre-existing trend between eligible and ineligibles driving the results.

Additional support for the parallel trends assumption, as well as justification for the interpretation that the DACA policy is driving the schooling and employment results, is offered in Figures 2 through 4 . The graphs display the coefficient estimates and the respective 90 percent confidence intervals from a regression model similar to the one in equation (1). The sole exception is that the DACA*eligibility term has been replaced by interaction terms between the eligibility indicator and a vector of year dummies. The latter are defined to begin in October of the stated year and run through September of the following year to mirror the timing of DACA. Again, we focus on a shorter window around treatment: October 2004 through the end of our sample.

As can be seen in Figures 2 through 4, the confidence intervals on the coefficient estimates corresponding to the eligibility indicator interacted with those years prior to DACA's implementation almost always include zero. Only the confidence intervals corresponding to the interaction between eligibility status and the years after DACA's implementation (Eligible_2012 and Eligible_2013) lie consistently below zero (in the case of school enrollment and full-time schooling) or above zero (in the case of employment). This pattern supports the

\footnotetext{
${ }^{15}$ As in Panel A, to mirror the timing of DACA, the new placebo indicator runs from October of the year of interest (October 2009) and, in this case, spans to the end of 2011.
} 
notion that: (a) there was no systematic trend in employment and schooling differences between eligible and non-eligible groups prior to DACA's implementation, and (b) the drop in schooling and rise in employment observed above, are strongly consistent with the timing of DACA.

\section{B. Capturing Undocumented Immigrants and DACA Applicants}

As recognized above, one limitation of the data is that it does not allow us to observe whether individuals are undocumented nor whether they have actually been granted a DACA reprieve and work authorization. While our sample already displays many of the traits characteristic of DACA applicants -including being close to twenty years old on average and having a high school degree (Batalova et al. 2013, Singer and Svajlenka 2013, Wong et al. 2013), one way we can address the aforementioned concern is by further restricting our sample to a group of immigrants with some of the known traits of DACA applicants and undocumented immigrants. Since the vast majority of DACA applications were ultimately approved, this also increases the likelihood that our estimates not only measure DACA-eligibility, but actual DACA take-up.

Thus, in Table 5, Panel A, we start by narrowing the main sample of highly-skilled non-citizens to those residing in one of the top nine states with the most DACA applicants. Note that this also happens to be a group of states with large populations of undocumented immigrants (Passel and Cohn 2009). Furthermore, the average age at arrival and U.S. residency for this sub-sample are, respectively, fourteen and seven -in line with the young ages at arrival and long U.S. residencies of DACA applicants (Singer and Svajlenka 2013). Once again, we observe how DACA was accompanied by a decline in the likelihood of being enrolled at school and being enrolled full-time of approximately 11 and 9 percentage points, respectively. And, while the estimated impact of DACA on the 
employment likelihood lies just below the threshold for statistical significance, its magnitude (about 9 percentage points) is similar to the one in Table 3, Panel A.

As an alternative robustness check that we are capturing both likely unauthorized migrants as well as DACA applicants, we next focus our attention on Hispanic non-citizens -a group more likely to capture unauthorized immigrants and DACA applicants (Passel and Cohn 2009, 2010; Singer and Svajlenka 2013). These results, displayed in Table 5, Panel B, continue to show a statistically significant decrease in the likelihood of school enrollment. However, the observed decline in employment probability is no longer statistically significant at conventional levels. Still, the magnitudes of the estimates remain similar to those in Table 3, Panel A.

Panel $\mathrm{C}$ of Table 5 goes further to restrict our sample of Hispanic noncitizens to those with 5 or more years of U.S. residency to address any remaining concerns regarding our control group and whether it includes foreign students. Despite the significantly smaller sample sizes, the results in Panel C continue to show evidence of a drop in the likelihood of school enrollment and full-time school enrollment, although the impact of DACA on the employment likelihood is not statistically significant in these smaller samples.

Lastly, we experiment with restricting our sample to just Mexican noncitizens -an ethnic immigrant group that is the most likely to be unauthorized and accounts for the vast majority of DACA applicants (Passel and Cohn 2009, 2010; Singer and Svajlenka 2013). On average, this group arrived in the United States when they were 12 years old and have resided in the United States more than 9 years. As shown in Table 5, Panel D, we observe a drop in the likelihood of being enrolled in school full-time (-10.4 percentage points) that is statistically significant at the 10 percent level; but possibly due, in part, to the significantly smaller sample, we find no statistically significant impacts on the remaining labor market outcomes. 


\section{Robustness to Treatment Assignment Date}

As noted earlier, the CPS does not contain information on DACA participation or when DACA approval was received. Assigning a later date may bias our estimates if some DACA-eligibles were actually treated before we assume them to be. To address that concern, we test the sensitivity of our results to choosing two slightly earlier treatment dates-one corresponding to the announcement of DACA in June 2012, and the other corresponding to the official implementation of DACA in August 2012. These are not falsification tests, as it is reasonable to expect that some eligible individuals could have reasonably changed their behavior in anticipation of treatment. Rather, we wish to gauge if our estimates of the impact of DACA are in a reasonable range based on slightly different treatment assignment dates.

Table 6, Panel A presents the results using the earliest treatment assignment month possible -that is, June 2012, the month in which DACA was announced. While this was earlier than any DACA-eligible individuals would have been granted DACA authorization, we might observe some impacts if individuals anticipated a conferral of benefits and behaved accordingly. Likewise, schools and employers may have anticipated a change in the treatment of undocumented immigrants and altered their behavior as well. The results in that panel are consistent with our interpretation, as we observe significant reductions in the likelihood of being enrolled in school and being enrolled fulltime similar in magnitude to those found in Table 3, Panel A. Similarly, we continue to find evidence of a statistically significant increase in the likelihood of employment.

Likewise, Table 6, Panel B presents the results using a treatment assignment date of August 2012 -the month in which DACA applications were first accepted. Results using this alternative date are very close to those in Table 6, Panel A, and the main results in Table 3, Panel A. Overall, the estimates in 
Table 6 suggest that anticipation of benefits under DACA were an important factor in the estimated responses captured in Table 3, Panel A.

\section{Heterogeneous Effects by Gender}

Finally, we decompose the main sample by gender to take into account the fact that employment patterns of male and female immigrants, in particular, are somewhat different and thus may display different responses to policy interventions. The results on the sub-sample of men are presented in Table 7, Panel A, while those for women can be found in Table 7, Panel B. We find evidence that, after October 2012, DACA-eligible men experienced a reduction in their school enrollment and full-time enrollment likelihood, at the same time they increased their employment likelihood. All three of the latter estimates $(-0.095$, -0.077 and 0.100 , respectively) are close in magnitude to the estimates for the overall sample. While women appear to experience similar impacts based on their point estimates, only the effects on the likelihood of being enrolled in school and full-time school enrollment (-0.119 and -0.143 , respectively) are statistically significant at conventional levels. Therefore, it seems that the main impact of DACA has been to reduce enrollment in higher education for eligible individuals, regardless of their gender. It also seems that DACA raised the employment likelihood of men, not women. However, we cannot rule out that the point estimates for men and women are statistically different. Finally, the two-year reprieve from deportation and work authorization does not yet appear to have significantly affected working hours or the wages earned by either men or women.

\section{Summary and Conclusions}

President Barack Obama announced the Deferred Action for Childhood Arrivals (DACA) initiative on June 15, 2012. The initiative, which first began to approve a significant number of cases in October 2012, was intended to provide 
eligible youth with a two-year reprieve from deportation and work authorization to allow them to come out of the shadows and enjoy better educational and labor market outcomes. In this paper, we rely on data from the Current Population Survey to gauge the impact that DACA has had on the schooling, employment and wages of eligible youth.

Despite some expectations that DACA would result in increased motivation to pursue higher education, we find that DACA significantly reduced the likelihood of school enrollment and full-time school enrollment of eligible youths who had already earned the schooling credentials required for DACA. In addition, there is some evidence of an improvement in the likelihood of employment among DACA-eligible males, suggesting that the potential labor market returns to authorization today might outweigh any additional returns to higher education to be felt further down the road. This behavior is consistent with an increased opportunity cost of college education for DACA-eligible individuals once DACA went into effect.

In sum, our results suggest that a lack of authorization inhibits undocumented individuals from efficient use of their time, which in this case manifests itself by an over-investment in schooling. Thus, once employment restrictions are relaxed, as with the implementation of DACA, eligible individuals may actually reduce their investments in schooling. It is worth noting, however, that our focus has been on the immediate, short-run impacts of DACA on schooling and labor market outcomes. Its long-run outcomes may differ. For instance, if large-scale immigration legalization efforts are realized, general equilibrium effects may ultimately reduce the opportunity costs of schooling and mitigate the drop in school enrollment observed here. Therefore, further analyses examining long-term impacts of the policy are warranted. 
Compliance with Ethical Standards:

The authors declare that they have no conflict of interest. 


\section{References}

Amuedo-Dorantes, Catalina, Cynthia Bansak, and Steven Raphael. 2007. "Gender Differences in the Labor Market: Impact of IRCA's Amnesty Provisions." American Economic Review, 97(2): 412-16.

Batalova, Jeanne, Sarah Hooker and Randy Capps. 2013. "Deferred Action for Childhood Arrivals at the One-Year Mark", Issue Brief, No. 8, August. Washington DC: Migration Policy Institute.

Black, Dan A., Terra G. McKinnish, and Seth G. Sanders. 2005. "Tight Labor Markets and the Demand for Educational Attainment: Evidence from the Coal Boom and Bust.” Industrial and Labor Relations Review, 59(1): 3-16.

Charles, Kerwin Kofi, Erik Hurst, and Matthew J. Notowidigdo. 2013. "Housing Booms, Labor Market Outcomes, and Educational Attainment." Unpublished manuscript. University of Chicago, Booth School of Business.

Constant, Amelie and Klaus F. Zimmermann. 2005a. "Immigrant Performance and Selective Immigration Policy: A European Perspective." National Institute Economics Review, 194(1): 94-105.

Constant, Amelie and Klaus F. Zimmermann. 2005b. "Legal Status at Entry, Economic Performance, and Self-employment Proclivity: A Bi-national Study of Immigrants.” IZA Discussion Paper No. 1910. 


\section{Department of Homeland Security, U.S. Citizenship and Immigration}

Services. 2013. "Deferred Action for Childhood Arrivals" data for August 2012June 30, 2013. Available at:

www.uscis.gov/USCIS/Resources/Reports\%20and\%20Studies/Immigration\%20F orms\%20Data/All\%20Form\%20Types/DACA/daca-13-7-12.pdf

\section{Department of Homeland Security, U.S. Citizenship and Immigration}

Services. 2015. Biometrics Capture Systems, CIS Consolidated Operational

Repository (CISCOR), December 2015.

Evans, William N. and Woo-Young Kim. 2008. "The Impact of Local Labor Market Conditions on the Demand for Educational Attainment: Evidence from Indian Casinos." Unpublished manuscript, University of Notre Dame.

Gathmann, Christina and Nicolas Keller. 2013. "Benefits of Citizenship? Evidence from Germany's New Immigration Policy." Unpublished manuscript. University of Heidelberg.

Gonzales, Roberto G. and Angie M. Bautista-Chavez. 2014. "Two Years and Counting: Assessing the Growing Power of DACA." American Immigration Council Report.

Immigration Policy Center. 2012. Creating Opportunity: The Economic Benefits of Granting Deferred Action to Unauthorized Immigrants Brought to the United States as Children, Washington DC: June 22. 
Kossoudji, Sherrie A. and Deborah A. Cobb-Clark. 2002. "Coming Out of the Shadows: Learning about Legal Status and Wages from the Legalized Population." Journal of Labor Economics, 20(3): 598-628.

National Immigration Law Center. 2005. The Economic Benefits of the DREAM Act and the Student Adjustment Act, Washington DC: February.

Passel, Jeffrey S. and D'Vera Cohn. “A Portrait of Unauthorized Immigrants in the United States." Washington, D.C. Pew Hispanic Center. April 14, 2009.

Passel, Jeffrey, and D'Vera Cohn. 2010. “U.S. Unauthorized Immigration Flows Are Down Sharply Since Mid-Decade." Washington DC: Pew Hispanic Center.

Passel, Jeffrey, and Mark Hugo Lopez. 2012. "Up to 1.7 Million Unauthorized Immigrant Youth May Benefit from New Deportation Rules." Washington DC: Pew Hispanic Center.

Passel, Jeffrey S., D'Vera Cohn, and Ana Gonzalez-Barrera. 2013. "Population Decline of Unauthorized Immigrants Stalls, May Have Reversed." Washington, D.C., Pew Research Center. September 23, 2013.

Preston, Julia and John H. Cushman Jr. "Obama to Permit Young Migrants to Remain in U.S." The New York Times. Published June 15, 2012. Accessed September 24, 2013. 
Rivera-Batiz, Francisco. 1999. "Undocumented Workers in the Labor Market: An Analysis of the Earnings of Legal and Illegal Mexican Immigrants in the United States.” Journal of Population Economics, 12(1): 91-116.

Singer, Audrey and Nicole Prchal Svajlenka. 2013. "Immigration Facts:

Deferred Action for Childhood Arrivals (DACA).” Brookings Institution. August 14, 2013. Available at:

http://www.brookings.edu/research/reports/2013/08/14-daca-immigration-singer

Wallsten, Peter. 2012. "Marco Rubio's DREAM Act Alternative a Challenge for Obama on Illegal Immigration.” The Washington Post. Published April 25, 2012. Accessed September 26, 2013.

Wong, Tom K., Angela S. García, Marisa Abrajano, Davide FitzGerald, Karthick Ramakrishnan and Sally Le. 2013. "Undocumented No More: A Nationwide Analysis of Deferred Action for Childhood Arrivals, or DACA", Center for American Progress: Washington DC, September. 
Figure 1: Number of DACA Applications Approved over Time

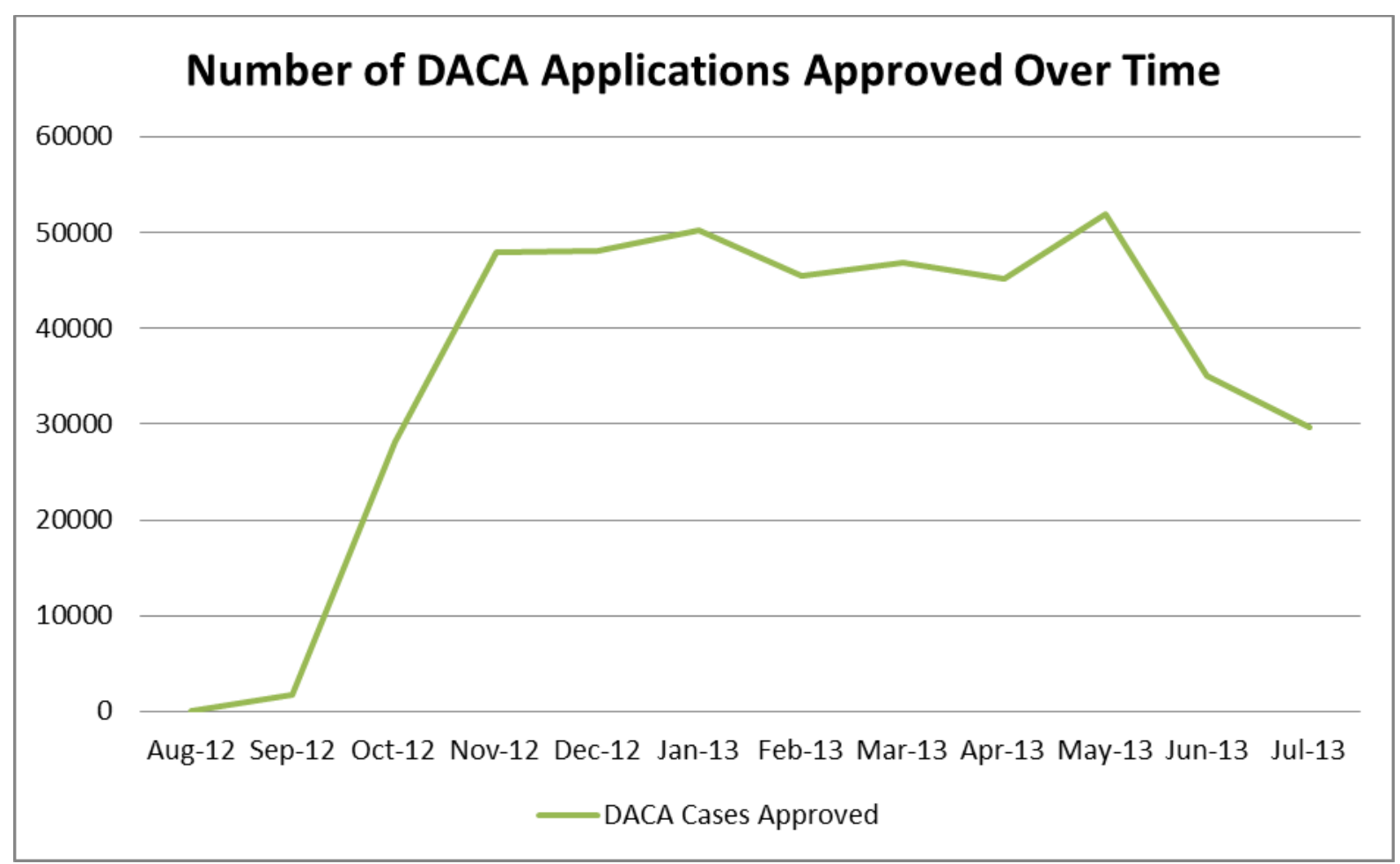

Source: USCIS data available at

http://www.uscis.gov/sites/default/files/USCIS/Resources/Reports\%20and\%20Studies/Immigration\%20Forms\%20Data/All\%20F orm\%20Types/DACA/daca-13-8-15.pdf 
Figure 2: School Enrollment Outcome

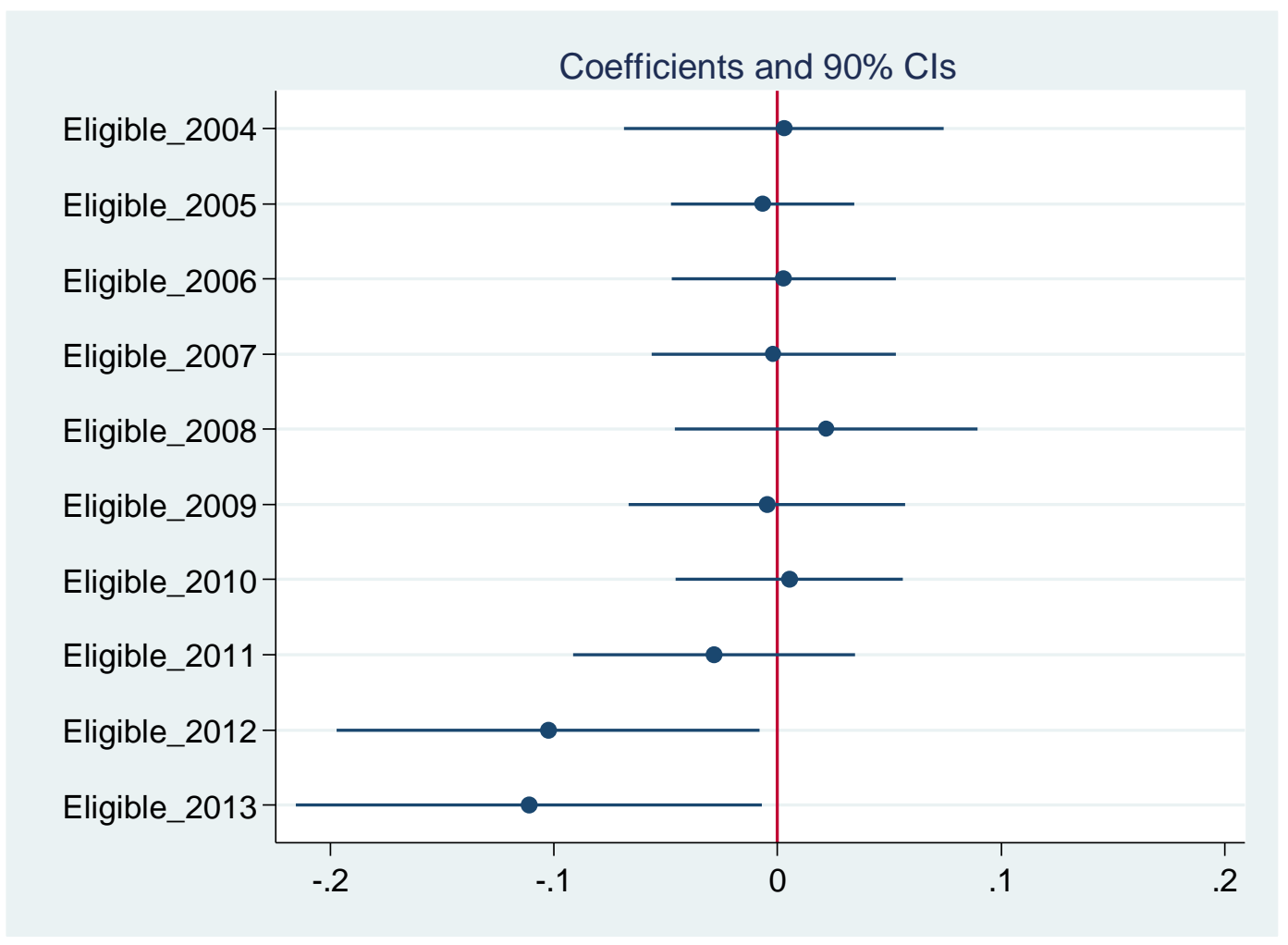

Notes: Graph shows coefficient estimates and confidence intervals from regression of indicator for being enrolled in school on the interactions between eligibility status and vector of year dummies where sample is restricted to cover October 2004 to March 2014. To coincide with the implementation timing of DACA, Year is defined to begin in October of stated year and run through September of following year. Note that the inclusion of all interaction terms absorbs the main effect of eligibility status, which is thus omitted from the specification. Other covariates in the regression (not shown) include: gender, race (white and black), marital status, indicators for age, years in the United States, number of children, educational attainment (more than HS), an indicator for whether the individual resides in a state with any of the following immigration enforcement measures: E-Verify mandate, omnibus immigration law or a $287(\mathrm{~g})$ agreement, a separate indicator for residing in a state granting in-state tuition for undocumented immigrants, and state-level unemployment rates. Additionally, all specifications include state fixed effects, month-year fixed effects, and state-specific linear time trends. Standard errors are clustered at the state level. 


\section{Figure 3: Full-time Student Outcome}

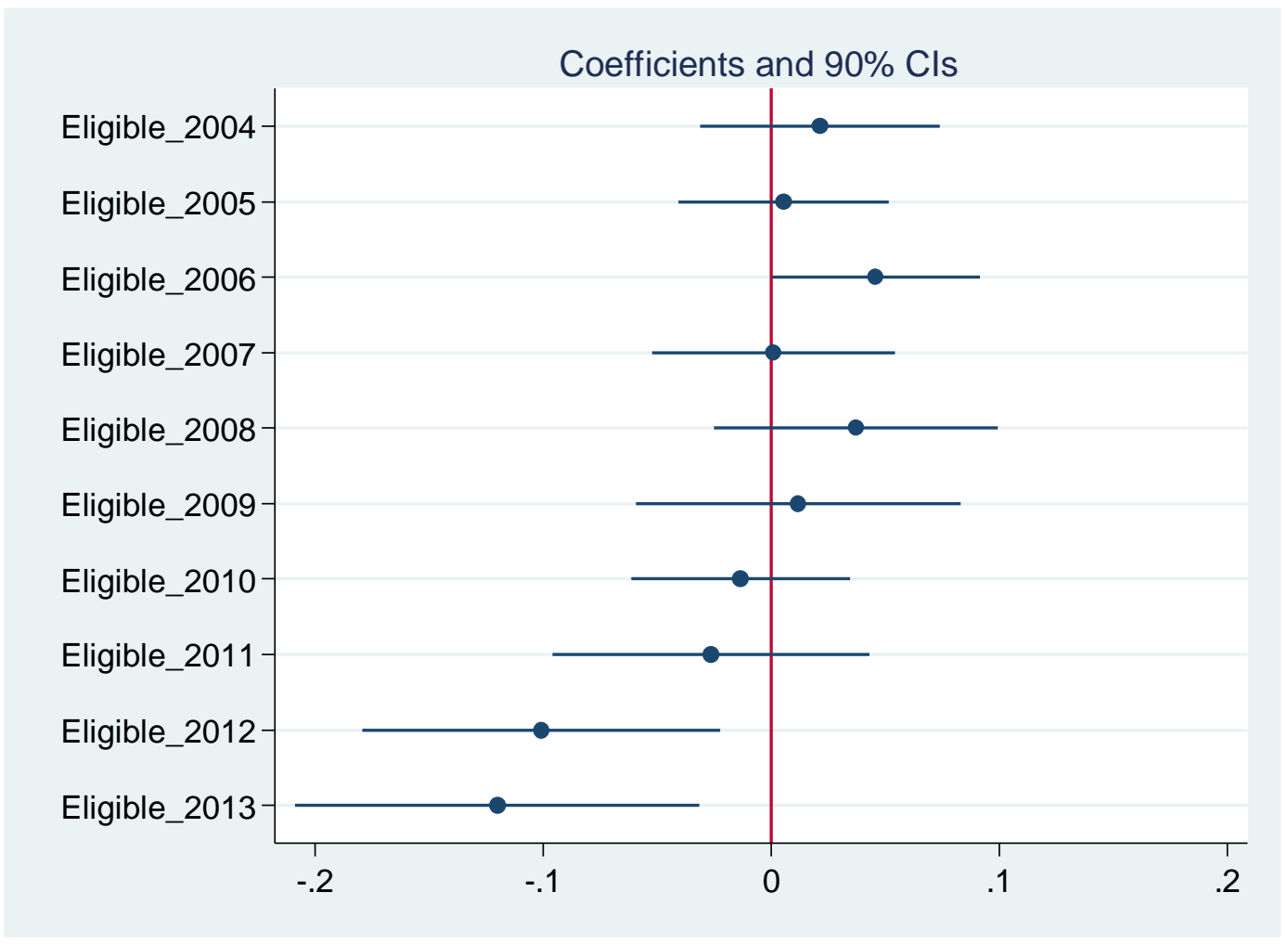

Notes: Graph shows coefficient estimates and confidence intervals from regression of indicator for being enrolled in school full-time on the interactions between eligibility status and vector of year dummies where sample is restricted to cover October 2004 to March 2014. To coincide with the implementation timing of DACA, Year is defined to begin in October of stated year and run through September of following year. Note that the inclusion of all interaction terms absorbs the main effect of eligibility status, which is thus omitted from the specification. Other covariates in the regression (not shown) include: gender, race (white and black), marital status, indicators for age, years in the United States, number of children, educational attainment (more than HS), an indicator for whether the individual resides in a state with any of the following immigration enforcement measures: E-Verify mandate, omnibus immigration law or a $287(\mathrm{~g})$ agreement, a separate indicator for residing in a state granting in-state tuition for undocumented immigrants, and state-level unemployment rates. Additionally, all specifications include state fixed effects, month-year fixed effects, and state-specific linear time trends. Standard errors are clustered at the state level. 


\section{Figure 4: Employment Outcome}

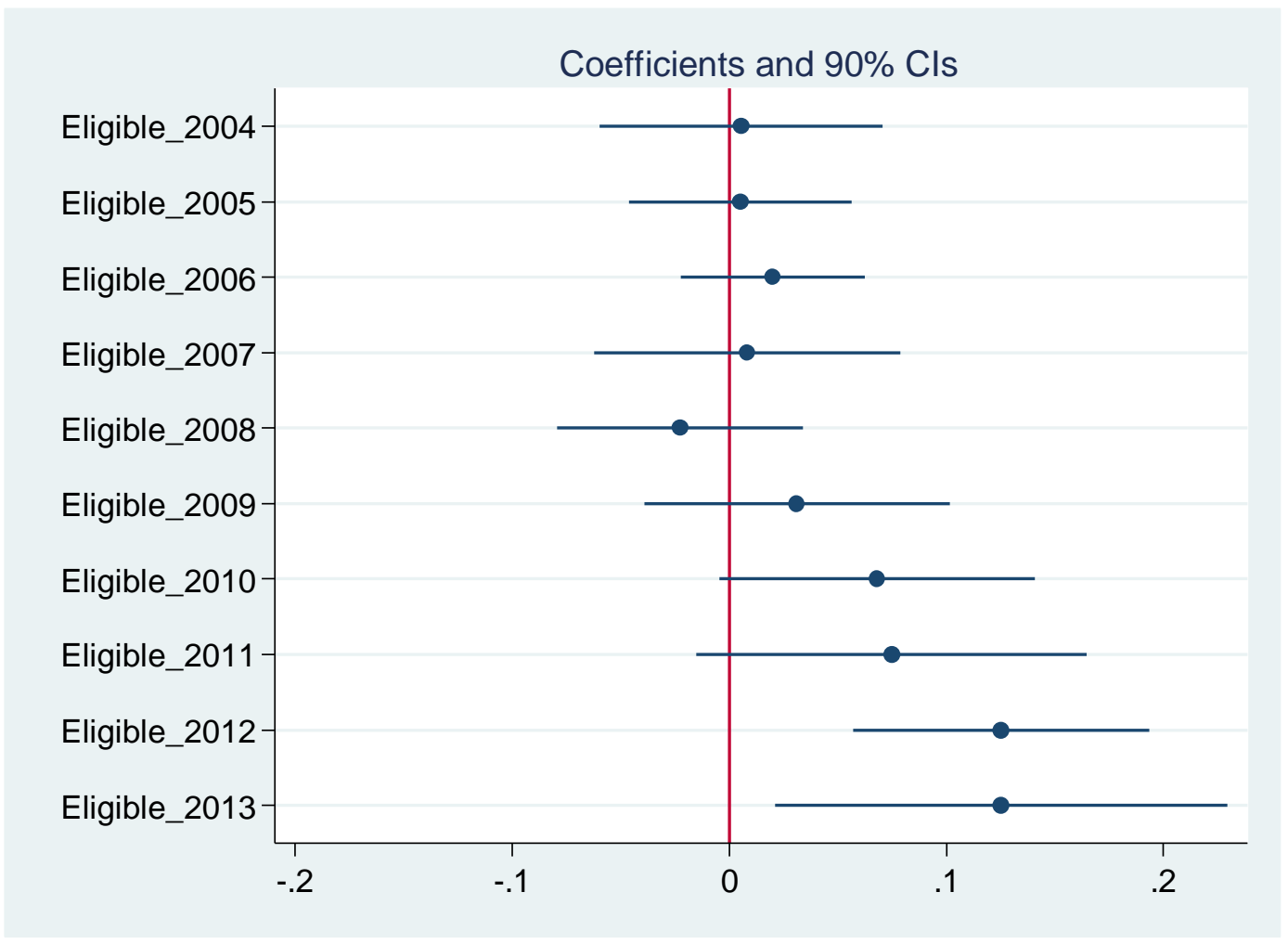

Notes: Graph shows coefficient estimates and confidence intervals from regression of indicator for being employed on the interactions between eligibility status and vector of year dummies where sample is restricted to cover October 2004 to March 2014. To coincide with the implementation timing of DACA, Year is defined to begin in October of stated year and run through September of following year. Note that the inclusion of all interaction terms absorbs the main effect of eligibility status, which is thus omitted from the specification. Other covariates in the regression (not shown) include: gender, race (white and black), marital status, indicators for age, years in the United States, number of children, educational attainment (more than HS), an indicator for whether the individual resides in a state with any of the following immigration enforcement measures: E-Verify mandate, omnibus immigration law or a 287(g) agreement, a separate indicator for residing in a state granting in-state tuition for undocumented immigrants, and state-level unemployment rates. Additionally, all specifications include state fixed effects, month-year fixed effects, and statespecific linear time trends. Standard errors are clustered at the state level. 
Table 1: Descriptive Statistics by Eligibility Status Pre- and Post-DACA

\begin{tabular}{|c|c|c|c|c|c|c|c|c|}
\hline \multirow{4}{*}{$\begin{array}{l}\text { Sample } \\
\text { Period } \\
\text { Group } \\
\text { Descriptive Statistic } \\
\end{array}$} & \multicolumn{8}{|c|}{ All Non-citizen 18-24 Years of Age with a High School Diploma or GED } \\
\hline & \multicolumn{4}{|c|}{ Pre-DACA } & \multicolumn{4}{|c|}{ Post-DACA } \\
\hline & \multicolumn{2}{|c|}{ Non-eligible } & \multicolumn{2}{|c|}{ Eligible } & \multicolumn{2}{|c|}{ Non-eligible } & \multicolumn{2}{|c|}{ Eligible } \\
\hline & Mean & S.D. & Mean & S.D. & Mean & S.D. & Mean & S.D. \\
\hline Eligible & 0.000 & 0.000 & 1.000 & 0.000 & 0.000 & 0.000 & 1.000 & 0.000 \\
\hline Age at Arrival & 17.423 & 4.449 & 8.616 & 4.600 & 19.913 & 2.265 & 7.594 & 4.213 \\
\hline Years in the U.S. & 4.568 & 4.419 & 12.134 & 4.748 & 2.093 & 1.859 & 13.626 & 4.266 \\
\hline Male & 0.516 & 0.500 & 0.504 & 0.500 & 0.490 & 0.500 & 0.490 & 0.500 \\
\hline White & 0.403 & 0.491 & 0.685 & 0.465 & 0.406 & 0.492 & 0.789 & 0.408 \\
\hline Black & 0.064 & 0.246 & 0.081 & 0.273 & 0.124 & 0.330 & 0.080 & 0.271 \\
\hline Age & 21.991 & 1.734 & 20.743 & 1.844 & 22.007 & 1.679 & 21.214 & 1.921 \\
\hline Married & 0.250 & 0.433 & 0.152 & 0.359 & 0.193 & 0.395 & 0.152 & 0.359 \\
\hline Number of Children & 0.213 & 0.569 & 0.187 & 0.524 & 0.154 & 0.498 & 0.207 & 0.576 \\
\hline High School & 0.495 & 0.500 & 0.517 & 0.500 & 0.308 & 0.462 & 0.528 & 0.500 \\
\hline More than High School & 0.505 & 0.500 & 0.483 & 0.500 & 0.692 & 0.462 & 0.472 & 0.500 \\
\hline Any State Immigration Enforcement & 0.120 & 0.325 & 0.188 & 0.391 & 0.269 & 0.444 & 0.321 & 0.467 \\
\hline In-state Tuition Policy State & 0.248 & 0.432 & 0.465 & 0.499 & 0.531 & 0.500 & 0.550 & 0.498 \\
\hline State Unemployment Rate & 5.528 & 1.889 & 6.754 & 2.533 & 6.598 & 1.416 & 6.808 & 1.458 \\
\hline Observations & \multicolumn{2}{|c|}{6,672} & \multicolumn{2}{|c|}{3,893} & \multicolumn{2}{|c|}{461} & \multicolumn{2}{|c|}{527} \\
\hline
\end{tabular}


Table 2: Differences-in-Differences

\begin{tabular}{|c|c|c|c|c|c|c|c|}
\hline \multicolumn{8}{|c|}{ Sample: All Non-citizen 18-24 Years of Age with a High School Diploma or GED } \\
\hline & \multicolumn{3}{|c|}{ Eligible Youth } & \multicolumn{3}{|c|}{ Non-eligible Youth } & \multirow{2}{*}{$\begin{array}{c}\text { DD } \\
\text { (DT-DC) }\end{array}$} \\
\hline & Pre-DACA & Post-DACA & DT & Pre-DACA & Post-DACA & DC & \\
\hline \multirow[t]{3}{*}{ Enrolled in School } & 0.420 & 0.342 & $-0.079 * * *$ & 0.331 & 0.527 & $0.196 * * *$ & $-0.275 * * *$ \\
\hline & [0.494] & [0.475] & $(0.023)$ & {$[0.471]$} & {$[0.500]$} & $(0.023)$ & $(0.032)$ \\
\hline & 3,893 & 527 & 4,420 & 6,672 & 461 & 7,133 & 11,553 \\
\hline \multirow[t]{3}{*}{ Full-time Student } & 0.347 & 0.266 & $-0.081 * * *$ & 0.273 & 0.477 & $0.205 * * *$ & $-0.285 * *$ \\
\hline & {$[0.476]$} & {$[0.442]$} & $(0.022)$ & {$[0.445]$} & {$[0.500]$} & $(0.022)$ & $(0.031)$ \\
\hline & 3,893 & 527 & 4,420 & 6,672 & 461 & 7,133 & 11,553 \\
\hline \multirow[t]{3}{*}{ Employed } & 0.574 & 0.605 & 0.031 & 0.615 & 0.432 & $-0.183 * * *$ & $0.215^{* * *}$ \\
\hline & [0.495] & [0.489] & $(0.023)$ & [0.487] & [0.496] & $(0.023)$ & $(0.033)$ \\
\hline & 3,893 & 527 & 4,420 & 6,672 & 461 & 7,133 & 11,553 \\
\hline \multirow[t]{3}{*}{ Weekly Work Hours } & 34.576 & 34.238 & -0.338 & 36.611 & 34.674 & $-1.937 * *$ & 1.599 \\
\hline & [10.978] & [11.707] & $(0.706)$ & [10.815] & [12.492] & $(0.858)$ & $(1.112)$ \\
\hline & 1,911 & 282 & 2,193 & 2,743 & 172 & 2,915 & 5,108 \\
\hline \multirow[t]{3}{*}{ Log Real Hourly Wages } & 2.311 & 2.259 & $-0.052 * *$ & 2.366 & 2.296 & -0.070 & 0.018 \\
\hline & {$[0.383]$} & {$[0.348]$} & $(0.024)$ & {$[0.478]$} & {$[0.389]$} & $(0.037)$ & $(0.044)$ \\
\hline & 1,911 & 282 & 2,193 & 2,743 & 172 & 2,915 & 5,108 \\
\hline \multirow[t]{3}{*}{ High Skill Occupation } & 0.122 & 0.113 & -0.009 & 0.183 & 0.209 & 0.026 & -0.035 \\
\hline & {$[0.328]$} & [0.318] & $(0.021)$ & [0.387] & [0.408] & $(0.031)$ & $(0.037)$ \\
\hline & 1,911 & 282 & 2,193 & 2,743 & 172 & 2,915 & 5,108 \\
\hline
\end{tabular}

Notes: Standard deviations are in brackets and standard errors are in parentheses. All regressions include a constant term. Additionally: $* p<0.1 ; * * p<0.05$; and $* * * p<0.01$. The number of observations is listed on the third row corresponding to each outcome. 
Table 3: Results for Highly Skilled (HS+) Non-citizens 18-24 Years of Age

\begin{tabular}{|c|c|c|c|c|c|c|}
\hline Key Regressors & $\begin{array}{l}\text { Likelihood of } \\
\text { Being } \\
\text { Enrolled in } \\
\text { School }\end{array}$ & $\begin{array}{l}\text { Likelihood of } \\
\text { Being } \\
\text { Enrolled in } \\
\text { School } \\
\text { Full-time } \\
\end{array}$ & $\begin{array}{c}\text { Likelihood of } \\
\text { Being } \\
\text { Employed }\end{array}$ & $\begin{array}{c}\text { Usual Weekly } \\
\text { Hours of } \\
\text { Work }\end{array}$ & $\begin{array}{l}\text { Log Real } \\
\text { Hourly } \\
\text { Wages }\end{array}$ & $\begin{array}{c}\text { Likelihood of } \\
\text { Working } \\
\text { in a } \\
\text { High Skill } \\
\text { Occupation }\end{array}$ \\
\hline Panel A & \multicolumn{6}{|c|}{ Sample Meeting the Educational Attainment Criterion Only } \\
\hline DACA*Eligible & $\begin{array}{c}-0.117 * * * \\
(0.030)\end{array}$ & $\begin{array}{c}-0.115^{* * * *} \\
(0.027)\end{array}$ & $\begin{array}{c}0.095 * * * \\
(0.035)\end{array}$ & $\begin{array}{l}-0.536 \\
(0.995)\end{array}$ & $\begin{array}{l}-0.018 \\
(0.054)\end{array}$ & $\begin{array}{l}-0.029 \\
(0.051)\end{array}$ \\
\hline Eligible & $\begin{array}{c}0.028 * * \\
(0.013)\end{array}$ & $\begin{array}{c}0.037 * * * \\
(0.011)\end{array}$ & $\begin{array}{l}-0.015 \\
(0.014)\end{array}$ & $\begin{array}{l}-0.676 \\
(0.509)\end{array}$ & $\begin{array}{l}0.026^{*} \\
(0.015)\end{array}$ & $\begin{array}{c}0.015 \\
(0.018)\end{array}$ \\
\hline $\begin{array}{l}\text { Observations } \\
\text { R-squared }\end{array}$ & $\begin{array}{c}11,553 \\
0.295\end{array}$ & $\begin{array}{c}11,553 \\
0.272\end{array}$ & $\begin{array}{c}11,553 \\
0.117\end{array}$ & $\begin{array}{l}5,108 \\
0.173\end{array}$ & $\begin{array}{l}5,108 \\
0.140\end{array}$ & $\begin{array}{l}5,108 \\
0.191\end{array}$ \\
\hline Panel B & \multicolumn{6}{|c|}{$\begin{array}{l}\text { Sample Meeting the Education, Arrival Date and Age Eligibility Criteria but Limited to: } \\
\text { Treated Sample: 13-15 years old at Arrival \& Control Sample: 16-18 years old at Arrival }\end{array}$} \\
\hline DACA*Eligible & $\begin{array}{c}-0.231 * * \\
(0.109)\end{array}$ & $\begin{array}{c}-0.239 * * \\
(0.097)\end{array}$ & $\begin{array}{c}0.125 \\
(0.187)\end{array}$ & $\begin{array}{c}7.520 \\
(5.273)\end{array}$ & $\begin{array}{c}0.128 \\
(0.173)\end{array}$ & $\begin{array}{c}0.072 \\
(0.116)\end{array}$ \\
\hline Eligible & $\begin{array}{c}0.004 \\
(0.054)\end{array}$ & $\begin{array}{c}0.010 \\
(0.059)\end{array}$ & $\begin{array}{l}-0.019 \\
(0.069)\end{array}$ & $\begin{array}{c}0.389 \\
(1.390)\end{array}$ & $\begin{array}{c}0.096 \\
(0.061)\end{array}$ & $\begin{array}{c}0.051 \\
(0.062)\end{array}$ \\
\hline $\begin{array}{l}\text { Observations } \\
\text { R-squared }\end{array}$ & $\begin{array}{l}1,739 \\
0.410\end{array}$ & $\begin{array}{l}1,739 \\
0.389\end{array}$ & $\begin{array}{l}1,739 \\
0.227\end{array}$ & $\begin{array}{l}1,019 \\
0.378\end{array}$ & $\begin{array}{l}1,019 \\
0.327\end{array}$ & $\begin{array}{l}1,019 \\
0.333\end{array}$ \\
\hline
\end{tabular}

Notes: $* p<0.1 ; * * p<0.05$; *** $p<0.01$. Other covariates include: gender, race (white and black), marital status, indicators for age, years in the United States, number of children, educational attainment (more than HS), an indicator for whether the individual resides in a state with any of the following immigration enforcement measures: E-Verify mandate, omnibus immigration law or a $287(\mathrm{~g})$ agreement, a separate indicator for residing in a state granting in-state tuition for undocumented immigrants, and state-level unemployment rates. Additionally, all specifications include state fixed effects, month-year fixed effects, and state-specific linear time trends. Standard errors are clustered at the state level. 
Table 4: Robustness Check for Pre-trends

(Sample: Highly Skilled Non-citizens 18-24 Years of Age)

\begin{tabular}{|c|c|c|c|c|c|c|}
\hline Key Regressors & $\begin{array}{l}\text { Likelihood } \\
\text { of Being } \\
\text { Enrolled in } \\
\text { School }\end{array}$ & $\begin{array}{c}\text { Likelihood } \\
\text { of Being } \\
\text { Enrolled in } \\
\text { School } \\
\text { Full-time } \\
\end{array}$ & $\begin{array}{c}\text { Likelihood } \\
\text { of Being } \\
\text { Employed }\end{array}$ & $\begin{array}{c}\text { Usual } \\
\text { Weekly } \\
\text { Hours of } \\
\text { Work } \\
\end{array}$ & $\begin{array}{l}\text { Log Real } \\
\text { Hourly } \\
\text { Wages }\end{array}$ & $\begin{array}{c}\text { Likelihood of } \\
\text { Working } \\
\text { in a High } \\
\text { Skill } \\
\text { Occupation } \\
\end{array}$ \\
\hline Panel A & \multicolumn{6}{|c|}{ Using Leads } \\
\hline DACA*Eligible & $\begin{array}{c}-0.122 * * * \\
(0.030)\end{array}$ & $\begin{array}{c}-0.123 * * * \\
(0.029)\end{array}$ & $\begin{array}{c}0.105 * * * \\
(0.039)\end{array}$ & $\begin{array}{l}-0.730 \\
(0.953)\end{array}$ & $\begin{array}{l}-0.019 \\
(0.051)\end{array}$ & $\begin{array}{l}-0.017 \\
(0.051)\end{array}$ \\
\hline Placebo 2011 *Eligible & $\begin{array}{l}-0.039 \\
(0.039)\end{array}$ & $\begin{array}{l}-0.041 \\
(0.042)\end{array}$ & $\begin{array}{c}0.047 \\
(0.047)\end{array}$ & $\begin{array}{l}-0.171 \\
(1.227)\end{array}$ & $\begin{array}{c}0.014 \\
(0.041)\end{array}$ & $\begin{array}{c}0.046 \\
(0.051)\end{array}$ \\
\hline Placebo $2010 *$ Eligible & $\begin{array}{c}-0.004 \\
(0.027)\end{array}$ & $\begin{array}{l}-0.027 \\
(0.029)\end{array}$ & $\begin{array}{c}0.052 \\
(0.037)\end{array}$ & $\begin{array}{c}-1.885^{*} \\
(1.033)\end{array}$ & $\begin{array}{l}-0.030 \\
(0.066)\end{array}$ & $\begin{array}{c}0.042 \\
(0.026)\end{array}$ \\
\hline Placebo $2009 *$ Eligible & $\begin{array}{l}-0.016 \\
(0.032)\end{array}$ & $\begin{array}{l}-0.003 \\
(0.034)\end{array}$ & $\begin{array}{c}0.013 \\
(0.048)\end{array}$ & $\begin{array}{c}-0.081 \\
(1.728)\end{array}$ & $\begin{array}{c}0.016 \\
(0.056)\end{array}$ & $\begin{array}{c}0.050 \\
(0.038)\end{array}$ \\
\hline Eligible & $\begin{array}{c}0.032 * * \\
(0.013)\end{array}$ & $\begin{array}{c}0.042 * * * \\
(0.012)\end{array}$ & $\begin{array}{l}-0.023 \\
(0.015)\end{array}$ & $\begin{array}{l}-0.509 \\
(0.572)\end{array}$ & $\begin{array}{c}0.026^{*} \\
(0.015)\end{array}$ & $\begin{array}{c}0.005 \\
(0.017)\end{array}$ \\
\hline $\begin{array}{l}\text { Observations } \\
\text { R-squared }\end{array}$ & $\begin{array}{c}11,553 \\
0.295\end{array}$ & $\begin{array}{c}11,553 \\
0.273\end{array}$ & $\begin{array}{c}11,553 \\
0.117\end{array}$ & $\begin{array}{l}5,108 \\
0.174\end{array}$ & $\begin{array}{l}5,108 \\
0.140\end{array}$ & $\begin{array}{l}5,108 \\
0.191\end{array}$ \\
\hline Panel B & \multicolumn{6}{|c|}{ Shorter Window Around Treatment } \\
\hline DACA*Eligible & $\begin{array}{c}-0.105^{* * *} \\
(0.032)\end{array}$ & $\begin{array}{c}-0.117 * * * \\
(0.029)\end{array}$ & $\begin{array}{c}0.100 * * * \\
(0.030)\end{array}$ & $\begin{array}{l}-0.275 \\
(0.945)\end{array}$ & $\begin{array}{l}-0.002 \\
(0.055)\end{array}$ & $\begin{array}{l}-0.041 \\
(0.052)\end{array}$ \\
\hline Eligible & $\begin{array}{c}-0.003 \\
(0.017)\end{array}$ & $\begin{array}{c}0.011 \\
(0.017)\end{array}$ & $\begin{array}{c}0.014 \\
(0.018)\end{array}$ & $\begin{array}{c}-0.259 \\
(0.668)\end{array}$ & $\begin{array}{c}0.028 \\
(0.022)\end{array}$ & $\begin{array}{c}0.020 \\
(0.020)\end{array}$ \\
\hline $\begin{array}{l}\text { Observations } \\
\text { R-squared }\end{array}$ & $\begin{array}{l}7,021 \\
0.308\end{array}$ & $\begin{array}{l}7,021 \\
0.290\end{array}$ & $\begin{array}{l}7,021 \\
0.134\end{array}$ & $\begin{array}{l}3,632 \\
0.190\end{array}$ & $\begin{array}{l}3,632 \\
0.134\end{array}$ & $\begin{array}{l}3,632 \\
0.180\end{array}$ \\
\hline Panel C & \multicolumn{6}{|c|}{ Falsification Test Using Pre-Period Sample } \\
\hline Placebo DACA*Eligible & $\begin{array}{l}-0.007 \\
(0.020)\end{array}$ & $\begin{array}{l}-0.024 \\
(0.024)\end{array}$ & $\begin{array}{c}0.042 \\
(0.031)\end{array}$ & $\begin{array}{l}-1.107 \\
(1.028)\end{array}$ & $\begin{array}{l}-0.009 \\
(0.041)\end{array}$ & $\begin{array}{c}0.031 \\
(0.020)\end{array}$ \\
\hline Eligible & $\begin{array}{c}0.000 \\
(0.017)\end{array}$ & $\begin{array}{c}0.022 \\
(0.016)\end{array}$ & $\begin{array}{c}-0.002 \\
(0.020)\end{array}$ & $\begin{array}{c}-0.412 \\
(0.779)\end{array}$ & $\begin{array}{c}0.013 \\
(0.024)\end{array}$ & $\begin{array}{l}-0.001 \\
(0.020)\end{array}$ \\
\hline $\begin{array}{l}\text { Observations } \\
\text { R-squared }\end{array}$ & $\begin{array}{l}5,538 \\
0.309\end{array}$ & $\begin{array}{l}5,538 \\
0.283\end{array}$ & $\begin{array}{l}5,538 \\
0.136\end{array}$ & $\begin{array}{l}2,951 \\
0.176\end{array}$ & $\begin{array}{l}2,951 \\
0.126\end{array}$ & $\begin{array}{l}2,951 \\
0.186\end{array}$ \\
\hline
\end{tabular}

Notes: $* p<0.1$; ** $p<0.05$; *** $p<0.01$. Each of these placebo indicators in Panel A equals 1 from October of the stated year through the following September to match the timing of the DACA indicator. The placebo in Panel C equals 1 from October of 2009 to December 2011. Other covariates include: gender, race (white and black), marital status, indicators for age, years in the United States, number of children, educational attainment (more than HS), an indicator for whether the individual resides in a state with any of the following immigration enforcement measures: E-Verify mandate, omnibus immigration law or a $287(\mathrm{~g})$ agreement, a separate indicator for residing in a state granting in-state tuition for undocumented immigrants, and state-level unemployment rates. Additionally, all specifications include state fixed effects, month-year fixed effects, and state-specific linear time trends. Standard errors are clustered at the state level. 
Table 5: Robustness Check to DACA Treatment - Likely Characteristics of DACA Applicants (Sample: Highly Skilled Non-citizens 18-24 Years of Age)

\begin{tabular}{|c|c|c|c|c|c|c|}
\hline Key Regressors & $\begin{array}{l}\text { Likelihood of } \\
\text { Being } \\
\text { Enrolled in } \\
\text { School }\end{array}$ & $\begin{array}{l}\text { Likelihood of } \\
\text { Being } \\
\text { Enrolled in } \\
\text { School } \\
\text { Full-time }\end{array}$ & $\begin{array}{c}\text { Likelihood of } \\
\text { Being } \\
\text { Employed }\end{array}$ & $\begin{array}{c}\text { Usual Weekly } \\
\text { Hours of } \\
\text { Work }\end{array}$ & $\begin{array}{l}\text { Log Real } \\
\text { Hourly } \\
\text { Wages }\end{array}$ & $\begin{array}{c}\text { Likelihood of } \\
\text { Working } \\
\text { in a } \\
\text { High Skill } \\
\text { Occupation }\end{array}$ \\
\hline Panel A & \multicolumn{6}{|c|}{ Residents of CA, TX, NY, IL, FL, NC, AZ, GA and NJ } \\
\hline DACA*Eligible & $\begin{array}{c}-0.107 * * \\
(0.044)\end{array}$ & $\begin{array}{c}-0.094 * * \\
(0.036)\end{array}$ & $\begin{array}{c}0.086 \\
(0.050)\end{array}$ & $\begin{array}{l}-1.083 \\
(1.317)\end{array}$ & $\begin{array}{c}0.076 \\
(0.050)\end{array}$ & $\begin{array}{c}0.039 \\
(0.044)\end{array}$ \\
\hline Eligible & $\begin{array}{c}0.037 * * \\
(0.013)\end{array}$ & $\begin{array}{c}0.053 * * * \\
(0.009)\end{array}$ & $\begin{array}{l}-0.010 \\
(0.018)\end{array}$ & $\begin{array}{l}-0.231 \\
(0.660)\end{array}$ & $\begin{array}{c}0.014 \\
(0.017)\end{array}$ & $\begin{array}{l}-0.006 \\
(0.017)\end{array}$ \\
\hline $\begin{array}{l}\text { Observations } \\
\text { R-squared }\end{array}$ & $\begin{array}{l}6,568 \\
0.290\end{array}$ & $\begin{array}{l}6,568 \\
0.267\end{array}$ & $\begin{array}{l}6,568 \\
0.135\end{array}$ & $\begin{array}{l}2,796 \\
0.199\end{array}$ & $\begin{array}{l}2,796 \\
0.138\end{array}$ & $\begin{array}{l}2,796 \\
0.197\end{array}$ \\
\hline Panel B & \multicolumn{6}{|c|}{ Hispanics } \\
\hline DACA*Eligible & $\begin{array}{c}-0.120 * * * \\
(0.044)\end{array}$ & $\begin{array}{c}-0.108 * * \\
(0.040)\end{array}$ & $\begin{array}{c}0.070 \\
(0.057)\end{array}$ & $\begin{array}{l}-0.237 \\
(2.070)\end{array}$ & $\begin{array}{c}0.026 \\
(0.068)\end{array}$ & $\begin{array}{c}-0.018 \\
(0.039)\end{array}$ \\
\hline Eligible & $\begin{array}{c}0.028 \\
(0.019)\end{array}$ & $\begin{array}{c}0.033 * * \\
(0.015)\end{array}$ & $\begin{array}{l}-0.016 \\
(0.022)\end{array}$ & $\begin{array}{l}-0.048 \\
(0.489)\end{array}$ & $\begin{array}{c}0.012 \\
(0.017)\end{array}$ & $\begin{array}{c}-0.002 \\
(0.015)\end{array}$ \\
\hline $\begin{array}{l}\text { Observations } \\
\text { R-squared }\end{array}$ & $\begin{array}{l}5,787 \\
0.275\end{array}$ & $\begin{array}{l}5,787 \\
0.242\end{array}$ & $\begin{array}{l}5,787 \\
0.164\end{array}$ & $\begin{array}{l}2,837 \\
0.216\end{array}$ & $\begin{array}{l}2,837 \\
0.172\end{array}$ & $\begin{array}{l}2,837 \\
0.162\end{array}$ \\
\hline Panel C & \multicolumn{6}{|c|}{ Hispanics with 5+ Years in the U.S. } \\
\hline DACA*Eligible & $\begin{array}{l}-0.158 * \\
(0.094)\end{array}$ & $\begin{array}{c}-0.209 * * \\
(0.097)\end{array}$ & $\begin{array}{c}0.154 \\
(0.108)\end{array}$ & $\begin{array}{l}-0.818 \\
(3.958)\end{array}$ & $\begin{array}{c}0.069 \\
(0.106)\end{array}$ & $\begin{array}{l}-0.017 \\
(0.091)\end{array}$ \\
\hline Eligible & $\begin{array}{c}-0.032 * * \\
(0.015)\end{array}$ & $\begin{array}{c}-0.011 \\
(0.014)\end{array}$ & $\begin{array}{c}0.013 \\
(0.026)\end{array}$ & $\begin{array}{l}1.502 * * \\
(0.669)\end{array}$ & $\begin{array}{c}0.020 \\
(0.018)\end{array}$ & $\begin{array}{l}-0.009 \\
(0.017)\end{array}$ \\
\hline $\begin{array}{l}\text { Observations } \\
\text { R-squared }\end{array}$ & $\begin{array}{l}3,940 \\
0.320\end{array}$ & $\begin{array}{l}3,940 \\
0.278\end{array}$ & $\begin{array}{l}3,940 \\
0.175\end{array}$ & $\begin{array}{l}1,969 \\
0.265\end{array}$ & $\begin{array}{l}1,969 \\
0.221\end{array}$ & $\begin{array}{l}1,969 \\
0.177\end{array}$ \\
\hline Panel D & \multicolumn{6}{|c|}{ Mexicans } \\
\hline DACA*Eligible & $\begin{array}{c}-0.072 \\
(0.051)\end{array}$ & $\begin{array}{l}-0.104 * \\
(0.056)\end{array}$ & $\begin{array}{c}0.011 \\
(0.069)\end{array}$ & $\begin{array}{l}-4.126 \\
(3.639)\end{array}$ & $\begin{array}{c}0.012 \\
(0.072)\end{array}$ & $\begin{array}{c}-0.004 \\
(0.059)\end{array}$ \\
\hline Eligible & $\begin{array}{c}0.001 \\
(0.024)\end{array}$ & $\begin{array}{c}0.028 * \\
(0.016)\end{array}$ & $\begin{array}{c}-0.006 \\
(0.029)\end{array}$ & $\begin{array}{c}0.854 \\
(0.688)\end{array}$ & $\begin{array}{c}0.007 \\
(0.021)\end{array}$ & $\begin{array}{c}-0.010 \\
(0.017)\end{array}$ \\
\hline $\begin{array}{l}\text { Observations } \\
\text { R-squared }\end{array}$ & $\begin{array}{l}3,112 \\
0.307\end{array}$ & $\begin{array}{l}3,112 \\
0.260\end{array}$ & $\begin{array}{l}3,112 \\
0.224\end{array}$ & $\begin{array}{l}1,768 \\
0.276\end{array}$ & $\begin{array}{l}1,768 \\
0.210\end{array}$ & $\begin{array}{l}1,768 \\
0.188\end{array}$ \\
\hline
\end{tabular}

Notes: $* p<0.1 ; * * p<0.05 ; * * * p<0.01$. Other covariates include: gender, race (white and black), marital status, indicators for age, years in the United States, number of children, educational attainment (more than HS), an indicator for whether the individual resides in a state with any of the following immigration enforcement measures: E-Verify mandate, omnibus immigration law or a $287(\mathrm{~g})$ agreement, a separate indicator for residing in a state granting in-state tuition for undocumented immigrants, and state-level unemployment rates. Additionally, all specifications include state fixed effects, month-year fixed effects, and state-specific linear time trends. Standard errors are clustered at the state level. 
Table 6: Robustness Check to Policy Timing - Experimenting with Alternative DACA Treatment Dates (Sample: Highly Skilled Non-citizens 18-24 Years of Age)

\begin{tabular}{|c|c|c|c|c|c|c|}
\hline Key Regressors & $\begin{array}{l}\text { Likelihood of } \\
\text { Being } \\
\text { Enrolled in } \\
\text { School }\end{array}$ & $\begin{array}{c}\text { Likelihood of } \\
\text { Being } \\
\text { Enrolled in } \\
\text { School } \\
\text { Full-time } \\
\end{array}$ & $\begin{array}{c}\text { Likelihood of } \\
\text { Being } \\
\text { Employed }\end{array}$ & $\begin{array}{c}\text { Usual Weekly } \\
\text { Hours of } \\
\text { Work }\end{array}$ & $\begin{array}{c}\text { Log Real } \\
\text { Hourly } \\
\text { Wages }\end{array}$ & $\begin{array}{c}\text { Likelihood of } \\
\text { Working } \\
\text { in a } \\
\text { High Skill } \\
\text { Occupation } \\
\end{array}$ \\
\hline Panel A & \multicolumn{6}{|c|}{ Using Enactment Date } \\
\hline DACA*Eligible & $\begin{array}{c}-0.105^{* * *} \\
(0.035)\end{array}$ & $\begin{array}{c}-0.096 * * * \\
(0.033)\end{array}$ & $\begin{array}{c}0.122 * * * \\
(0.042)\end{array}$ & $\begin{array}{l}-0.491 \\
(1.134)\end{array}$ & $\begin{array}{l}-0.033 \\
(0.055)\end{array}$ & $\begin{array}{l}-0.027 \\
(0.053)\end{array}$ \\
\hline Eligible & $\begin{array}{c}0.030 * * \\
(0.013)\end{array}$ & $\begin{array}{c}0.040 * * * \\
(0.012)\end{array}$ & $\begin{array}{l}-0.018 \\
(0.014)\end{array}$ & $\begin{array}{l}-0.792 \\
(0.522)\end{array}$ & $\begin{array}{l}0.026 * \\
(0.015)\end{array}$ & $\begin{array}{c}0.015 \\
(0.018)\end{array}$ \\
\hline $\begin{array}{l}\text { Observations } \\
\text { R-squared }\end{array}$ & $\begin{array}{c}11,167 \\
0.293\end{array}$ & $\begin{array}{c}11,167 \\
0.270\end{array}$ & $\begin{array}{c}11,167 \\
0.117\end{array}$ & $\begin{array}{l}4,938 \\
0.169\end{array}$ & $\begin{array}{l}4,938 \\
0.140\end{array}$ & $\begin{array}{l}4,938 \\
0.192\end{array}$ \\
\hline Panel B & \multicolumn{6}{|c|}{ Using Implementation Date } \\
\hline DACA*Eligible & $\begin{array}{c}-0.106 * * * \\
(0.026)\end{array}$ & $\begin{array}{c}-0.107 * * * \\
(0.024)\end{array}$ & $\begin{array}{c}0.103 * * * \\
(0.032)\end{array}$ & $\begin{array}{l}-0.396 \\
(0.965)\end{array}$ & $\begin{array}{c}0.000 \\
(0.050)\end{array}$ & $\begin{array}{l}-0.005 \\
(0.045)\end{array}$ \\
\hline Eligible & $\begin{array}{c}0.028 * * \\
(0.013)\end{array}$ & $\begin{array}{c}0.038 * * * \\
(0.012)\end{array}$ & $\begin{array}{c}-0.017 \\
(0.014)\end{array}$ & $\begin{array}{l}-0.682 \\
(0.521)\end{array}$ & $\begin{array}{c}0.025 \\
(0.015)\end{array}$ & $\begin{array}{c}0.013 \\
(0.018)\end{array}$ \\
\hline $\begin{array}{l}\text { Observations } \\
\text { R-squared }\end{array}$ & $\begin{array}{c}11,553 \\
0.295\end{array}$ & $\begin{array}{c}11,553 \\
0.272\end{array}$ & $\begin{array}{c}11,553 \\
0.117\end{array}$ & $\begin{array}{l}5,108 \\
0.173\end{array}$ & $\begin{array}{l}5,108 \\
0.140\end{array}$ & $\begin{array}{l}5,108 \\
0.191\end{array}$ \\
\hline
\end{tabular}

Notes: $* p<0.1 ; * * p<0.05$; *** $p<0.01$. Other covariates include: gender, race (white and black), marital status, indicators for age, years in the United States, number of children, educational attainment (more than HS), an indicator for whether the individual resides in a state with any of the following immigration enforcement measures: E-Verify mandate, omnibus immigration law or a $287(\mathrm{~g})$ agreement, a separate indicator for residing in a state granting in-state tuition for undocumented immigrants, and state-level unemployment rates. Additionally, all specifications include state fixed effects, month-year fixed effects, and state-specific linear time trends. Standard errors are clustered at the state level. 
Table 7: Results for Highly Skilled Non-citizens 18-24 Years of Age by Gender

\begin{tabular}{|c|c|c|c|c|c|c|}
\hline Key Regressors & $\begin{array}{c}\text { Likelihood of } \\
\text { Being } \\
\text { Enrolled in } \\
\text { School }\end{array}$ & $\begin{array}{c}\text { Likelihood of } \\
\text { Being } \\
\text { Enrolled in } \\
\text { School } \\
\text { Full-time } \\
\end{array}$ & $\begin{array}{c}\text { Likelihood of } \\
\text { Being } \\
\text { Employed }\end{array}$ & $\begin{array}{c}\text { Usual Weekly } \\
\text { Hours of } \\
\text { Work }\end{array}$ & $\begin{array}{c}\text { Log Real } \\
\text { Hourly } \\
\text { Wages }\end{array}$ & $\begin{array}{c}\text { Likelihood of } \\
\text { Working } \\
\text { in a } \\
\text { High Skill } \\
\text { Occupation } \\
\end{array}$ \\
\hline Panel A & \multicolumn{6}{|c|}{ Men } \\
\hline DACA*Eligible & $\begin{array}{c}-0.095 * * \\
(0.041)\end{array}$ & $\begin{array}{c}-0.077 * * \\
(0.035)\end{array}$ & $\begin{array}{c}0.100 * * \\
(0.037)\end{array}$ & $\begin{array}{c}0.004 \\
(1.776)\end{array}$ & $\begin{array}{l}-0.019 \\
(0.062)\end{array}$ & $\begin{array}{l}-0.026 \\
(0.053)\end{array}$ \\
\hline Eligible & $\begin{array}{c}0.024 \\
(0.021)\end{array}$ & $\begin{array}{c}0.025 \\
(0.017)\end{array}$ & $\begin{array}{c}-0.014 \\
(0.017)\end{array}$ & $\begin{array}{l}-0.192 \\
(0.794)\end{array}$ & $\begin{array}{c}0.025 \\
(0.027)\end{array}$ & $\begin{array}{c}0.042 * * \\
(0.021)\end{array}$ \\
\hline $\begin{array}{l}\text { Observations } \\
\text { R-squared }\end{array}$ & $\begin{array}{l}5,891 \\
0.319\end{array}$ & $\begin{array}{l}5,891 \\
0.296\end{array}$ & $\begin{array}{l}5,891 \\
0.170\end{array}$ & $\begin{array}{l}2,899 \\
0.206\end{array}$ & $\begin{array}{l}2,899 \\
0.171\end{array}$ & $\begin{array}{l}2,899 \\
0.272\end{array}$ \\
\hline Panel B & \multicolumn{6}{|c|}{ Women } \\
\hline DACA*Eligible & $\begin{array}{c}-0.119 * * \\
(0.059)\end{array}$ & $\begin{array}{c}-0.143 * * * \\
(0.048)\end{array}$ & $\begin{array}{c}0.075 \\
(0.050)\end{array}$ & $\begin{array}{l}-1.034 \\
(1.634)\end{array}$ & $\begin{array}{c}0.014 \\
(0.064)\end{array}$ & $\begin{array}{c}0.002 \\
(0.074)\end{array}$ \\
\hline Eligible & $\begin{array}{l}0.029 * \\
(0.015)\end{array}$ & $\begin{array}{c}0.048 * * * \\
(0.018)\end{array}$ & $\begin{array}{l}-0.018 \\
(0.023)\end{array}$ & $\begin{array}{l}-1.164 \\
(0.791)\end{array}$ & $\begin{array}{c}0.016 \\
(0.019)\end{array}$ & $\begin{array}{l}-0.043 \\
(0.026)\end{array}$ \\
\hline $\begin{array}{l}\text { Observations } \\
\text { R-squared }\end{array}$ & $\begin{array}{l}5,662 \\
0.313\end{array}$ & $\begin{array}{l}5,662 \\
0.291\end{array}$ & $\begin{array}{l}5,662 \\
0.121\end{array}$ & $\begin{array}{l}2,209 \\
0.222\end{array}$ & $\begin{array}{l}2,209 \\
0.182\end{array}$ & $\begin{array}{l}2,209 \\
0.221\end{array}$ \\
\hline
\end{tabular}

Notes: $* p<0.1 ; * * p<0.05$; *** $p<0.01$. Other covariates include: gender, race (white and black), marital status, indicators for age, years in the United States, number of children, educational attainment (more than HS), an indicator for whether the individual resides in a state with any of the following immigration enforcement measures: E-Verify mandate, omnibus immigration law or a $287(\mathrm{~g})$ agreement, a separate indicator for residing in a state granting in-state tuition for undocumented immigrants, and state-level unemployment rates. Additionally, all specifications include state fixed effects, month-year fixed effects, and state-specific linear time trends. Standard errors are clustered at the state level. 
Appendix Table A1: High- and Low-Skill Occupations

\begin{tabular}{|c|c|}
\hline \multicolumn{2}{|r|}{ High skill Occupations } \\
\hline 1 & "Management occupations" \\
\hline 2 & "Business and financial operations occupations" \\
\hline 3 & "Computer and mathematical science occupations" \\
\hline 4 & "Architecture and engineering occupations" \\
\hline 5 & "Life, physical, and social science occupations" \\
\hline 6 & "Community and social service occupations" \\
\hline 7 & "Legal occupations" \\
\hline 8 & "Education, training, and library occupations" \\
\hline 9 & "Arts, design, entertainment, sports, and media" \\
\hline 10 & "Healthcare practitioner and technical occupations" \\
\hline \multicolumn{2}{|r|}{ Low skill Occupations } \\
\hline 11 & "Healthcare support occupations" \\
\hline 12 & "Protective service occupations" \\
\hline 13 & "Food preparation and serving related occupations" \\
\hline 14 & "Building and grounds cleaning and maintenance" \\
\hline 15 & "Personal care and service occupations" \\
\hline 16 & "Sales and related occupations" \\
\hline 17 & "Office and administrative support occupations" \\
\hline 18 & "Farming, fishing, and forestry occupations" \\
\hline 19 & "Construction and extraction occupations" \\
\hline 20 & "Installation, maintenance, and repair occupations" \\
\hline 21 & "Production occupations" \\
\hline 22 & "Transportation and material moving occupations" \\
\hline 23 & "Armed Forces" \\
\hline
\end{tabular}


Appendix Table A2: Results for Non-citizens 18-24 Years of Age of All Educational Attainments

\begin{tabular}{lcccccc}
\hline Key Regressors & $\begin{array}{c}\text { Likelihood of } \\
\text { Being } \\
\text { Enrolled in } \\
\text { School }\end{array}$ & $\begin{array}{c}\text { Likelihood of } \\
\text { Being } \\
\text { Enrolled in } \\
\text { School } \\
\text { Full-time }\end{array}$ & $\begin{array}{c}\text { Likelihood of } \\
\text { Being } \\
\text { Employed }\end{array}$ & $\begin{array}{c}\text { Usual } \\
\text { Weekly } \\
\text { Hours of } \\
\text { Work }\end{array}$ & $\begin{array}{c}\text { Log Real } \\
\text { Hourly } \\
\text { Wages }\end{array}$ & $\begin{array}{c}\text { Likelihood of } \\
\text { Working } \\
\text { in a } \\
\text { High Skill } \\
\text { Occupation }\end{array}$ \\
\hline Sample & \multicolumn{7}{c}{ Non-citizen Men and Women } & & \\
\hline DACA*Eligible & $-0.117 * * *$ & $-0.115^{* * *}$ & $0.068 * * *$ & 0.218 & -0.014 & -0.013 \\
Eligible & $(0.029)$ & $(0.026)$ & $(0.025)$ & $(0.693)$ & $(0.036)$ & $(0.030)$ \\
Observations & $0.212^{* * *}$ & $0.189 * * *$ & $-0.059^{* * *}$ & $-1.941 * * *$ & -0.016 & -0.009 \\
R-squared & $(0.010)$ & $(0.010)$ & $(0.011)$ & $(0.348)$ & $(0.014)$ & $(0.012)$ \\
& 19,177 & 19,177 & 19,177 & 8,063 & 8,063 & 8,063 \\
\end{tabular}

Notes: $* p<0.1$; ** $p<0.05$; *** $p<0.01$. Other covariates include: gender, race (white and black), marital status, indicators for age, years in the United States, number of children, educational attainment (HS and more than HS), an indicator for whether the individual resides in a state with any of the following immigration enforcement measures: E-Verify mandate, omnibus immigration law or a $287(\mathrm{~g})$ agreement, a separate indicator for residing in a state granting in-state tuition for undocumented immigrants, and state-level unemployment rates. Additionally, all specifications include state fixed effects, month-year fixed effects, and state-specific linear time trends. Standard errors are clustered at the state level. 